Georgetown University Law Center

Scholarship @ GEORGETOWN LAW

1997

\title{
When Dispute Resolution Begets Disputes of its Own: Conflicts Among Dispute Professionals
}

Carrie Menkel-Meadow

Georgetown University Law Center, meadow@law.georgetown.edu

This paper can be downloaded free of charge from:

https://scholarship.law.georgetown.edu/facpub/1762

44 UCLA L. Rev. 1871

This open-access article is brought to you by the Georgetown Law Library. Posted with permission of the author. Follow this and additional works at: https://scholarship.law.georgetown.edu/facpub

Part of the Dispute Resolution and Arbitration Commons, and the Legal Profession Commons 


\title{
WHEN DISPUTE RESOLUTION BEGETS DISPUTES OF ITS OWN: CONFLICTS AMONG DISPUTE PROFESSIONALS
}

\author{
Carrie Menkel-Meadow*
}

I. THE PURPOSES OF ADR: EFFICIENCY, QUALTTY, OR JUSTICE VALUES $\ldots \ldots \ldots \ldots \ldots \ldots \ldots \ldots \ldots \ldots \ldots \ldots \ldots \ldots \ldots \ldots$

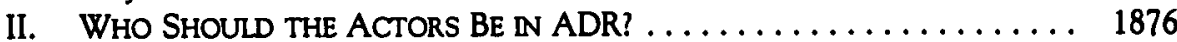

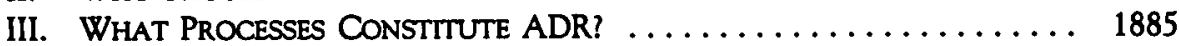

IV. To WHAT USES SHOUID ADR BE PUT? . . . . . . . . . . . . . . 1897

V. ETHICS AND STANDARDS IN THE USE OF ADR:

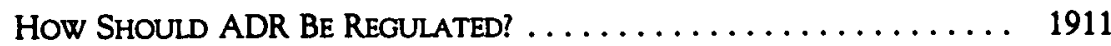

VI. EVALUATIONS OF ADR: DOES IT WORK?

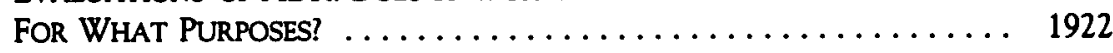

VII. RESOLVING THE DISPUTES AMONG DISPUTE PROFESSIONALS:

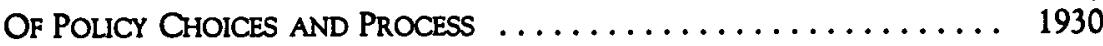

As the processes comprising. alternative, or as we now say, "appropriate" dispute resolution mature and enter new phases of use, new issues have emerged to demonstrate that professionals engaged in providing dispute resolution services have disputes and conflicts among themselves. This Article reviews some of those conflicts and issues and suggests some resolutions for these disputes between dispute resolvers.

\section{THE PURPOSES OF ADR: EFFICIENCY, QUALITY, OR JUSTICE VALUES}

Since the beginning of the modern ADR movement, there have been at least two strands of argument supporting the use of alternatives to fullscale legal adjudication by judge or jury. On the one hand is the claim that ADR will ensure speedy, less costly, and therefore more efficient case processing. This strand of the movement has been called the quantitative, caseload-reducing, or case management side of ADR and is the main reason many jurists and court administrators support ADR. At its most elementary level, this argument relies on the promise of Rule 1 of the Federal Rules of Civil Procedure that the purpose of courts and rules is to "secure the just, speedy and inexpensive determination of every action."

* Professor of Law, UCLA School of Law; Co-Director, Center on Inter-Racial/Inter-Ethnic Conflict Resolution, UCLA; Professor of Law, Georgetown University; and Chair, CPRGeorgetown Commission on Ethics and Standards in ADR. Thanks and appreciation to two wonderful research assistants, Edward Kim and Elena Ro.

1. FED. R. CIV. P. 1. 
Another strand of ADR emphasizes the qualitative argument that both dispute processes and their outcomes can be improved with alternatives to full-scale trial. Those who focus on process suggest that ADR provides for more party participation and control over the proceedings, a greater possibility of resolving more than the particular "dispute" at hand, and reconciliation ${ }^{2}$ or better communication between disputing parties.

In addition, for those who focus on outcomes, ADR promises the possibility of more Pareto optimal solutions ${ }^{3}$ in which bipolar results are avoided, ${ }^{4}$ compromises may not be necessary, ${ }^{5}$ and parties' underlying interests may be explored and hopefully met. Furthermore, ADR promotes the adoption of more complex solutions that are tailored to the parties' needs or situation. In earlier work, I described courts' "limited remedial imagination" to grant injunctions, award damages, or declare parties innocent or guilty, liable or not liable. In ADR we can look to the future, as well as the past, ${ }^{7}$ and involve many more parties than the traditional adversarial system allows. ADR promotes solutions that are more flexible and responsive to party needs, as well as to nonparties affected by the resolution of a particular dispute. Thus, the argument goes, ADR provides better outcomes than traditional adjudication in which litigation can only deal with the resolution of disputed facts of past events, even while making rules (but not solutions) for the future.

2. See Robert A. Baruch Bush \& Joseph P. Folger, The Promise of Mediation: RESPONDING TO CONFLICT THROUGH EMPOWERMENT AND RECOGNITION 96-97 (1994); Andrew W. McThenia \& Thomas L. Shaffer, For Reconciliation, 94 YALE L.J. 1660 (1985).

3. A "Pareto optimal" solution is one in which the maximum feasible joint gains have been achieved; any further benefit to one side would come at a cost to the other. See HOWARD RAiffa, THE ART AND SCIENCE OF Negotiation 139 (1982).

4. I am not one of those who argues for the popular win-win solutions. Many legal disputes cannot be resolved by having both parties win something, but they may still be better resolved than having one party lose all, as often occurs in trial or decisional settings. The popular formulation of win-win is, in my view, inaccurate, and leads to false expectations or hopes about what can be accomplished in dispute resolution settings.

5. For my views on how ADR does not always require compromise, see Carrie MenkelMeadow, Whose Dispute Is It Anyway? A Philosophical and Democratic Defense of Settlement (In Some Cases), 83 GEO. L.J. 2663, 2672-78 (1995).

6. Carrie Menkel-Meadow, Toward Another View of Legal Negotiation: The Structure of Problem Solving, 31 UCLA L. Rev. 754, 789-94 (1984).

7. For the importance of considering both the past and the future (contrary to the more common ideology of exploring only the future possibilities) in mediation, see Carrie MenkelMeadow, What Trina Taught Me: Reflections on Mediation, Inequality, Teaching and Life, 81 MiNN. L. REv. 1413, 1419 (1997) (commenting on Trina Grillo's observations that past harms should not be lost in the future orientation of problem solving in mediation); see also Trina Grillo, The Mediation Altemative: Process Dangers for Women, 100 YALE L.J. 1545 (1991). 
In addition to these two strands of argument, researchers have recently raised subsets of these purposes or goals, some of them to modify either quantitative or qualitative arguments; others raise their own demands or conflicts with currently existing justifications for ADR. Some argue that ADR provides a place in which disputes can be settled privately, without embarrassing the parties, while others suggest that disputing and its resulting outcomes ought to be public. ${ }^{8}$ Thus, there is an inevitable tension between dispute resolution's private function and its public function. For many, this tension is as important as how we measure justice and fairness in our system." Is the "justice" of a dispute resolution process to be judged by what it accomplishes for the parties inside the dispute or by what rules or norms it provides to the larger society for subsequent behavioral guidance? A related concern, very much at the heart of today's political and budgetary issues, concerns whether dispute choices should be publicly or privately funded. ${ }^{10}$ For others, fairness or justice in dispute resolution is measured by how it affects individuals involved in the disputes. ${ }^{11}$

For some, ADR embraces both qualitative and quantitative goals by potentially increasing access to the justice system, by offering different modes of dispute processing, by increasing the number of fora available, and by providing litigants with a "day in court" rather than a settlement arranged exclusively by their lawyers. ${ }^{12}$ Others argue that provisions of alternatives will eventually stabilize demand for dispute resolution as the availability of $A D R$ programs decreases the queue to trial and provides its own equilibrium point. ${ }^{13}$ As access to ADR increases, the wait for trial will decrease and more litigants will again choose trial; eventually an equilibrium point will be reached, perhaps at a higher access level.

8. See, e.g., David Luban, Settlements and the Erosion of the Public Realm, 83 GEO. L.J. 2619 (1995). For a recent argument that ADR should be subject to the constitutional regulation of public law processes, see Richard C. Reuben, Public Justice: Toward a State Action Theory of ADR, 85 CAL. L. ReV. 577 (1997).

9. See Owen M. Fiss, Against Settlement, 93 YALE L.J. 1073 (1984); Luban, supra note 8, at 2631-40.

10. See Lisa Bernstein, Understanding the Limits of Court-Connected ADR: A Critique of Federal Court-Annexed Arbitration Programs, 141 U. PA. L. Rev. 2169 (1993); Rex E. Lee, The American Courts as Public Goods: Who Should Pay the Costs of Litigation?, 34 CATH. U. L. REV. 267 (1985); Steven Shavell, Altemative Dispute Resolution: An Economic Analysis, 24 J. LEGAL STUD. 1 (1995).

11. See, e.g., BUSH \& FOLGER, supra note 2; Menkel-Meadow, supra note 5.

12. See Frank E.A. Sander, Varieties of Dispute Processing, 70 F.R.D. 111 (1976); D. Brock Hornby, Federal Court-Annexed ADR: After the Hoopla, FJC DiRECTIONS, Dec. 1994, at 26.

13. See George L. Priest, Private Litigants and the Court Congestion Problem, 69 B.U. L. REv. $527,557-59$ (1989). 
At its most controversial, some ADR proponents, including myself, suggest that the use of different processes, techniques, and approaches to problem solving might actually tame the adversarial beast, providing both more humane ways of dealing with disputes and encouraging different approaches to conflict outcomes. ${ }^{14}$ To the extent that adversarialism in the legal system either mirrors or perpetuates the adversarial culture of war, sports, and other destructive forms of competition and conflict, alternate forms of dispute "handling" with our differences, conflicts, and need to allocate scarce resources. ${ }^{16}$ Whereas some suggest that forms of ADR and alternative models of conflict resolution are particularly appropriate for including affected parties ${ }^{17}$ and broadening the accountability of both the public and dispute resolvers, others suggest that only traditional forms of litigation can guarantee public accountability. ${ }^{18}$

14. See, e.g., Carrie Menkel-Meadow, The Trouble with the Adversary System in a Postmodem, Multicultural World, 38 WM. \& MARY L. REV. 5 (1996); see also BUSH \& FOLGER, supra note 2, at 81-83 (arguing that mediation can "transform" the parties in terms of their orientations to each other and also in terms of their own individual empowerment).

15. I resist here, as elsewhere, the terms "conflict resolution" and "conflict management," both of which assume that conflict is always to be put down, suppressed, or controlled. I suggest instead that some degree of conflict is healthy but that alternative forms of conflict "handling" help us to channel this conflict productively into useful solutions to problems, statements of issues, and opportunities to deal constructively with our differences. My aversion to adversarialism stems from my desire to avoid declaring "winners and losers" when it is unnecessary and to note that the learning that adversarialism breeds is often exaggerated, distorted, and generally unhelpful to resolving problems.

16. Much of the argument for traditional legal problem solving (adversarial trial resolution or adversarial negotiation) posits a world, or at least a dispute, of scarce resources in which someone has to gain at the expense of the other. See AVINASH K. DIXIT \& BARRY J. NALEBUfF, THINKING StRATEGICALlY: THE COMPETITIVE EDGE IN BUSINESS, POLITICS, and EVERYDAY LIFE (1991); LESTER C. THUROW, THE ZERO-SUM SOCIETY 4 (1980). Many legal problems have elements of this distributive allocative problem, but others do not and can benefit from "expanding the pie" or "creating value" before the pie must be cut or the value claimed. For an excellent effort to analyze the multi-dimensionality of most conflicts, see P.H. GULLIVER, Disputes and Negotiations: A Cross-Cultural Perspective (1979); David A. Lax \& James K. Sebenius, The Manager as Negotiator (1986). For a recent argument demonstrating the limits of more integrative bargaining, see Gerald B. Wetlaufer, The Limits of Integrative Bargaining, 85 GEO. L.J. 369 (1996).

17. Such as in the public policy disputes implicated in environmental, siting, budget allocation, and community issues. See LAWRENCE SUSSKIND \& JefFreY CRUIKSHANK, BrEAKING THE IMPASSE (1987) [hereinafter BREAKING THE IMPASSE]; LAWRENCE SUSSKIND \& PATRICK Field, Dealing with an Angry public: The mutual gains approach to Resolving DISPUTES (1996).

18. See, e.g., Fiss, supra note 9; Luban, supra note 8. For the Susskind and Stulberg debate about the accountability of mediators in environmental disputes, see Lawrence Susskind, Environmental Mediation and the Accountability Problem, 6 VT. L. REV. 1 (1981); Joseph Stulberg, The Theory and Practice of Mediation: A Reply to Professor Susskind, 6 VT. L. REV. 85 (1981). 
Thus, when we consider the question of what we will do when adjudication "ends," we will have differences among us concerning the purposes of our courts and adjudication, ${ }^{19}$ and the purposes and goals of alternatives to traditional litigation. Are we trying to resolve disputes, both private and public, produce precedents and rules to guide the rest of society, educate the populace and professionals about kinder, gentler arts of conflict resolution, ${ }^{20}$ or simply tame the crushing civil ${ }^{21}$ case load by diverting cases to other fora? The debates surrounding the purpose and goals of our dispute resolution processes are illustrated every day in divergences in jurisprudential assumptions or arguments about our system by academics and judges and perhaps, more significantly, by practitioners of dispute resolution who increasingly practice their craft(s) with different goals and processes that inform different techniques and behavioral choices, and that, in turn, implicate serious ethical, moral, political, and other dilemmas. I hope to illuminate some of these intellectual, philosophical, and practical differences and consider whether and how we should resolve these conflicts and disputes so that we may guarantee justice and fairness to all those who use dispute resolution processes. ${ }^{22}$ In addition, every area of dispute or conflict contains systemic, or macro-level issues, as well as behavioral, or micro-level issues to consider. Thus, deciding whether, how, and at what level to regulate the practice of ADR itself remains one of the conflicts among dispute resolvers. ${ }^{23}$

19. See Martin Shapiro, A Comparative and Polttical ANalysis (1981); Stephen C. Yeazell, The Misunderstood Consequences of Modem Civil Process, 1994 WIS. L. REV. 631.

20. See David N. Smith, A Warmer Way of Disputing: Mediation and Conciliation, 26 AM. J. COMP. L. 365 (Supp. 1978).

21. Actually, the caseload problem in most courts is a product of the criminal docket, rather than the civil docket. Many courts report some decrease in civil filings in recent years. See ADMINISTRATIVE OfFICE OF THE U.S. COURTS, 1995 FEDERAL COURT MANAGEMENT STATISTICS (1995); Stephanie Simon, Civil Courts Also Feel Squeeze of ' 3 Strikes' Cases, L.A. TIMES, Aug. 13, 1995, at A1.

22. This is more than an academic concern for me. I currently chair the CPR-Georgetown Commission on Ethics and Standards in ADR, a group of public interest, judicial, academic, and legal practice professionals who are concerned about whether and how regulation of the field should be conducted.

23. There are currently many competing attempts to regulate aspects of dispute resolution practice. At the level of professional associations, see AAA, ETHICAL STANDARDS FOR ARBITRATORS (1977) [hereinafter ETHICAL STANDARDS]; AAA-ABA-SPIDR, JOINT STANDARDS FOR CONDUCT OF MEDIATORS (1994) [hereinafter JOINT STANDARDS]; ACADEMY OF FAMILY Mediators, ABA FAMILY LAW SECTION STANDARDS FOR MEDIATORS (1984); Carrie MenkelMeadow, Professional Responsibility for Third Party Neutrals, 11 ALTERNATIVES 129 (1993). For examples of state regulatory schemes, see 5 FLA. STAT. ch. 44.106 (1990). See ALTERNATIVE DisPUTE RESOLUTION REVIEW BD., RULE 114 CODE OF ETHICS (proposed Jan. 7, 1997) (providing for the Minnesota General Rules of Practice that ADR must be considered for nearly all civil cases filed in district court); Robert B. Moberly, Ethical Standards for Court-Appointed 


\section{WHO SHOULD THE ACTORS BE IN ADR?}

While some forms of ADR are thousands of years old, modern ADR has its roots in both the private and public sector. Thus, issues emerged early in the debate about ADR as to whether alternatives to courts should be privately conducted (as in older historical cases of ADR) and privately funded, or supported by public institutions and the public fisc (a relatively new development). ${ }^{24}$ Today, the debates about whether ADR is more appropriately allocated to the private sector ${ }^{25}$ or the public sector are heating up as Congress, along with state legislatures, decide whether to fund court-annexed ADR programs. ${ }^{26}$

In the 1970s, during the earliest stages of modern ADR, Professor Frank Sander suggested that dispute resolution promised a court function, which he labeled the "multi-door courthouse," a dream that has been realized in a number of state and federal courts that have experimented with ADR fora such as mediation, arbitration, early neutral evaluation, settlement conferences, "ombuds," and summary jury trial. The federal Law

Mediators and Florida's Mandatory Mediation Experiment, 20 FLA. ST. U. L. REV. 701 (1994). For federal rules and regulations, see, for example, ElIZABETH PLAPINGER \& DONNA STIENSTRA, ADR ANd SeTtlement IN THE Federal District COURTS (1996), and ROBERT J. Niemic, Mediation and Conference Programs In the Federal Courts of Appeals (1997). For examples of local rules, see Joshua D. Rosenberg \& H. Jay Folberg, Altemative Dispute Resolution: An Empirical Analysis, 46 STAN. L. Rev. 1487 (1994) (reviewing the operation of the Early Neutral Evaluation program of the Northern District of California's ADR program).

24. For a thoughtful exploration of the arguments for and against the role of ADR in federal courts outlining some of the public versus private issues, see DONNA STIENSTRA \& THOMAS E. Willging, Alternatives to Litigation: Do They Have a Place IN the Federal District COURTS? (1995).

25. See Shavell, supra note 10 , and Bernstein, supra note 10 , for arguments that ADR does not provide enough "value added" to the public to justify its use in public institutions and that parties who want it can contract for it privately and pay for it privately. See also William M. Landes \& Richard A. Posner, Adjudication as a Private Good, 8 J. LegAL STUD. 235 (1979).

26. The Civil Justice Reform Act, and its support of several ADR experiments, demonstrations, and pilot projects, "sunsets" at the end of this year. Following consideration of reports done by RAND and the Federal Judicial Center on these programs, the Judicial Conference will make recommendations to Congress about whether to continue both authorization and appropriations for these programs. See JAMES S. KAKALIK ET AL., RAND INST. FOR CIVIL JUSTICE,

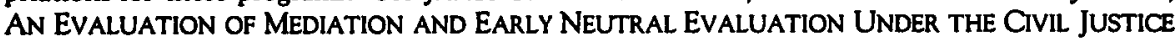
REFORM ACT (1996) [hereinafter RAND ADR REPORT]; JAMES S. KAKALIK ET AL., RAND INST. FOR CIVIl JUSTICE, JUST, SPEEDY AND INEXPENSIVE? AN EVAluation of Judicial CASE MANAGEMENT UNDER THE CIVIL JUSTICE REFORM ACT (1996) [hereinafter RAND CASE MANAGEMENT REPORT]; DONNA STIENSTRA ET AL., FEDERAL JUDICIAL CTR., A STUDY OF THE Five Demonstration Programs Established Under the CiVIL Justice ReForm ACt OF 1990 (1997) [hereinafter FJC REPORT ON ADR]. 
Enforcement Assistance Administration (LEAA) agency ${ }^{27}$ provided early funding for experiments in four cities with alternative ways to deal with minor criminal and civil disputes ${ }^{28}$ through Neighborhood Justice Centers, ${ }^{29}$ which utilized primarily mediation services. Critics suggested that such programs diverted minor disputes from the courts, just as subordinated people were gaining access through law reform efforts in civil rights, landlord-tenant, consumer, and other areas of substantive law. ${ }^{30}$

At the other end of the economic spectrum, however, well-financed and represented disputants were developing private ADR fora in order to choose their decisionmakers, ${ }^{31}$ tailor the rules, lessen the costs of litigation and discovery, and seek more confidential modes of dispute resolution. ${ }^{32}$ In addition, these litigants sought more efficient justice when court backlogs in some states ran as high as five or more years. In 1980, a group of Fortune 500 companies and their lawyers founded the Center for Public Resources to explore private dispute resolution and to avoid the higher costs of litigation when disputing with each other. ${ }^{33}$ Thus, while some critics suggested that ADR only shunted the lower-end case and individual litigants out of the system, others complained that the wealthier and more

27. The LEAA is a federally funded program devoted to crime and dispute reduction with a variety of programs supported. See CHRISTINE B. HARRINGTON, SHADOW JUSTICE (1985).

28. See Harrington, supta note 27; THE POltTics of INFORMal Justice: THE AMERICAN EXPERIENCE (Richard L. Abel ed., 1982).

29. In Los Angeles, Dispute Resolution Services, a non-profit organization, provides disputeresolution services to Los Angeles courts, individuals, and community groups. The organization is now funded by the Los Angeles County Bar Association.

30. See, e.g., Richard L. Abel, The Contradictions of Informal Justice, in THE Polrrics of INFORMal JUSTICE, supta note 28; Laura Nader, Controlling Processes in the Practice of Law: Hierarchy and Pacification in the Movement to Re-form Dispute Ideology, 9 OHIO ST. J. ON DISP. RESOL. 1 (1993).

31. This has historically been the norm in commercial disputing. See JEROLD S. AuERBACH, Justice WITHOUT LAW? (1983); YVES DEZALAY \& BRyaNT G. GaRTH, DEALING IN VIRTUE: INTERNATIONAL COMMERCIAL ARBITRATION AND THE CONSTRUCTION OF A Transnational legal Order (1996); IAN Macneil et al., Federal Arbitration law (1994).

32. An example of one such private ADR forum is the use of California's Rent-a-Judge program in Johnny Carson's divorce proceedings. See Richard Chernick, The Rent-a-Judge Option, L.A. LAW., Oct. 1989, at 18-19; see also ERIC GREEN, THE CPR LEGAL ProGrAm MINI-TRIAL HANDBOOK (1982) (discussing the TRW $v$. Telecredit dispute and the creation of the private minitrial); Eric D. Green, Growth of the Mini-Trial, LITIG., Fall 1982, at 12; Eric D. Green et al., Settling Large Case Litigation: An Altemate Approach, 11 LoY. L.A. L. REv. 493 (1978).

33. The "CPR Pledge," in which member corporations promise to first explore ADR, rather than to litigate with each other, currently has over 3000 corporate signatories, as well as a lawfirm pledge in which over 1500 law firms have pledged to educate themselves and their clients about uses of ADR to avoid the high costs of litigation. See CPR Homepage (last modified July $15,1997)<$ http://www.cpradr.org $>$. 
influential litigants were leaving the system and would thus be less interested in judicial reform efforts. ${ }^{34}$

The reality remains that ADR is currently being used both in smaller cases $^{35}$ and in the largest and most complex cases. ${ }^{36}$ In addition, ADR is used in public programs through court-annexed arbitration and mediation and summary jury trial, as well as in private sectors, through mini-trials, mediation, arbitration, and more sophisticated hybrids developed to meet the tailored needs of disputants. In the public sector, entire agencies have developed ADR programs, ${ }^{37}$ and the administrative regulatory process has been experimenting with various forms of $A D R,{ }^{38}$ including a new process called "regulatory-negotiation," or "reg-neg," which attempts to discourage litigation by bringing interested stakeholders into the regulation-creation process by facilitating large-scale negotiations before a regulation is finalized, rather than waiting for post-regulation comment and litigation.

Thus, while debates continue about whether ADR should remain a private process or receive state support and funding, it is likely that both

34. See, e.g., Judith Resnik, Failing Faith: Adjudicatory Procedure in Decline, 53 U. CHI. L. Rev. 494 (1986) [hereinafter Resnik, Failing Faith]; Judith Resnik, Many Doors? Closing Doors? Altemative Dispute Resolution and Adjudication, 10 OHIO ST. J. ON DISP. RESOL. 211, 255-57 (1995).

35. In some federal courts, this means any case below $\$ 150,000$ in value, see, e.g., N.D. CAL. R. 4-2(a), and in many state programs means any case below $\$ 50,000$ in pleaded value.

36. See, e.g., Todd H. Bailey, Summary Jury Trial Settles $\$ 250$ Million Case Three Years After First Attempt at ADR Failed, 14 ALTERNATIVES 75 (1996); Minitrial Achieves Settlement in Mammoth Case, 9 ALTERNATIVES 155 (1991); Minitrial Yields \$130M Result in Utility Case, 10 ALTERNATIVES 129 (1992); SJT Spurs $\$ 78$ Million Accord, 7 ALTERNATIVES 149 (1989); Two-Day ADR Ends Water Pollution Cases, 11 ALTERNATIVES 89 (1993).

37. For example, army procurement contracts and the FDIC. See CATHY A. CONSTANTINO \& Christina Sickles Merchant, Designing CONflict Management Systems 34 (1996); WILLIAM L. URY ET AL.; GETTING DISPUTES RESOLVED 101-33 (1988).

38. See Jody Freeman, Collaborative Govemance in the Administrative State, 45 UCLA L. REV. (forthcoming 1997); Philip J. Harter, Negotiating Regulations: A Cure for Malaise, 71 GEO. L.J. 1 (1982); Lawrence Susskind \& Gerard McMahon, The Theory and Practice of Negotiated Rulemaking, 3 YALE J. ON REG. 133 (1985). 
will nevertheless continue, ${ }^{39}$ and the lines of regulatory concern may or may not merge. ${ }^{40}$ Thus, the question of whether the public sector should provide ADR services implicates deep jurisprudential issues about the roles of judges and courts, with the disputes waged at the level of establishing credentials and standards for the providers already actively engaged in dispensing ADR, whether of the decision kind (arbitration) or the settlement kind (mediation). ${ }^{41}$ Should only those, like judges, who have been through a public confirmation or election process decide cases (with the accountability that comes from such processes), or can private individuals with little or no formal credentials manage cases just as well, and with what accountability?

To the extent that some feel that ADR is more appropriately a private function that parties should choose and finance, it is important to consider the likely effects of privatizing the justice system and dispute resolution. ${ }^{42}$ There is the obvious problem of access, for if these private justice goods are desirable, then why should only those who can afford them be able to choose them? In addition, if the most well-endowed leave the system, who will care for and pay for the work and effort it takes to create reforms in the

39. Bryant Garth has argued that there is now an economic, as well as political legitimacy, competition underway between the public and private sectors as they compete for dispute resolution business. See Bryant G. Garth, Privatization and the New Market for Disputes: A Framework for Analysis and a Preliminary Assessment, in 12 STUdIES IN LAW, POLrmos \& SOCIETY 367 (Susan S. Silbey \& Austin Sarat eds., 1992); see also Yves Dezalay \& Bryant Garth, Fussing About the Forum, 21 L. \& SOC. INQUIRY 285 (1996); Bryant Garth, From Civil Litigation to Private Justice: Legal Practice at War with the Profession and lits Values, 59 BROOK. L. REv. 931 (1993).

40. In some courts, for example, privately certified mediators are automatically placed on court lists. See Kansas federal court program described in PLAPINGER \& STIENSTRA, supra note 23. In other jurisdictions, public agencies and courts develop their own statutory or "credeh̀tializing" criteria. See, e.g., 5 FLA. STAT. ch. 44.106 (1990); Donald T. Weckstein, Mediator Certification: Why and How, 30 U.S.F. L. REV. 757 (1996).

41. See Jeffrey W. Stempel, Reflections on Judicial ADR and the Multi-Door Courthouse at Twenty: Fait Accompli, Failed Overture, or Fledgling Adulthood?, 11 OHIO ST. J. ON DISP. RESOL. 297 (1996).

42. See Jack B. Weinstein, Some Benefits and Risks of Privatization of Justice Through ADR, 11 OHIO ST. J. ON DISP. RESOL. 241 (1996). 
public justice system? ${ }^{43}$ Also, with the allocation of dispute resolution to private fora, there is a danger that all governmental decision making could be privatized through private legislation (in block-grant settlement processes and other resource-allocation decisions, ${ }^{44}$ siting disputes ${ }^{45}$ ) and privatized regulatory or executive decision making. In other words, without some public stake in court-annexed or public forms of dispute resolution, there is a danger that judicial, as well as other forms of governmental functions and decision-making, may devolve to the private sector. Thus, questions surrounding who becomes, and stays, involved in the practice and regulation of ADR may be important for reasons beyond the resolution of particular disputes. To the extent that both public issues, as well as public political choices are made and aired in individual disputes, the argument goes, processes should be public too!

Lest one think this reflects some unlikely reverse-Orwellian dystopia of privatization rather than state domination, consider the battles between the privatization of international commercial law through private arbitration ${ }^{46}$ and current struggles to keep international trade disputes in the public international arena through formal court adjudication ${ }^{47}$ in dispute resolution bodies like WTO and GATT. ${ }^{48}$ Indeed, in debates about private versus public, more formal modes of disputing are salient in the international as well as domestic spheres.

At the individual level, disputes surrounding who should "do" ADR in some sense mirror the public-private split. In its current state of early

43. This argument is similar to the one against private judging in California-the claim of a "brain drain" or talent drain away from the bench. See JANICE A. ROEHL ET AL., PRIVATE JUDGING: A STUDY OF ITS VOLUME, NATURE, AND IMPACT ON STATE COURTS: FINAL REPORT (1993) (studying California's Rent-a-Judge procedures authorized by article VI, section 21 of the California Constitution, California Court Rule 244, and section 638 of the California Code of Civil Procedure). See also Elizabeth Rolph et al., Escaping the Courthouse: Private Altemative Dispute Resolution in Los Angeles, 2 J. DISP. RESOL. 277 (1996).

44. For one critical look at mediation in some resource allocation disputes, see Janet Neuman, Run, River, Run: Mediation of a Water-Rights Dispute Keeps Fish and Farmers Happy-For a Time, 67 U. COLO. L. REV. 259 (1996).

45. See, e.g., Denis Brion, Essential Industry and the NIMBY Phenomenon, 9 YALE J. ON REG. 274 (1992); Brian D. Malkmus, Note, Johnson v. Sunray Services, Inc.: Possible Solutions to the NIMBY Syndrome, 45 ARK. L. REV. 657 (1992); Michael Wheeler, Negotiating NIMBYs: Leaming from the Failure of the Massachusetts Siting Law, 11 YALE J. ON REG. 241 (1994).

46. See Dezalay \& GarTH, supra note 31 .

47. See Paul D. Carrington \& Paul H. Haagen, Contract and Jurisdiction, 1996 SuP. CT. REV. 331, 345-46 (1997).

48. See Christlan Buhring-Uhle, ARbitration and Mediation IN INTERNational BUSINESS (1996). 
professionalization, ${ }^{49}$ ADR is a fluid field, attracting practitioners from a number of different disciplinary backgrounds, including accounting, psychotherapy, economics, labor relations, social work, and law. "Turf" battles over who will conduct mediation sessions are played out in proposed regulatory, licensing, and "credentializing" schemes, with each profession claiming its disciplinary knowledge is essential to the task. For example, both psychologists and lawyers, lay special claim to domestic relations expertise, as lawyers and accountants lay claim to valuation disputes, and architects begin to get involved in the forensics of construction arbitration-as decisionmakers as well as experts. If attorneys lay claim to the legal expertise required in dispute settlement, can psychologists lay claim to the process expertise of facilitating communication? ? $^{50}$

Some argue that much dispute resolution implicates the practice of law $^{51}$ because of the application of general legal principles to concrete facts $^{52}$ in a spectrum of ADR practices. These practices range from the simple facilitation of communication, ${ }^{53}$ to reality testing and the probing of the legal merits of a case, to evaluation or opinions (in joint or private sessions), to prediction, ${ }^{54}$ to solution suggestion. The legal implications of reliance on third-party neutrals by nonparties ${ }^{55}$ may lead to liability ${ }^{56}$ and

49. For the stages of development of a profession, see, for example, ELIOT FRIEDSON, PROFESSIONAL POWERS: A STUDY OF THE INSTITUTIONALIZATION OF FORMAL KNOWLEDGE (1986); MAgali Sarfatti LARSON, THe Rise of Professionalism (1977); Andrew Abbott, Status and Strain in the Professions, 86 AM. J. SoC. 819 (1981).

50. This has been suggested to me by my psychologist colleague Dr. Howard Gadlin, UCLA University Ombudsperson.

51. See Carrie Menkel-Meadow, Is Mediation the Practice of Law?, 14 ALTERNATIVES 57 (1996); cf. Bruce Meyerson, Lawyers Who Mediate Are Not Practicing Law, 14 ALTERNATIVES 74 (1996). The Florida Mediator Qualifications Advisory Panel has recently ruled that mediators may not give legal information to parties because that would constitute legal advice. See Fla. MQAP, Op. 96-003 (1997).

52. For definitions of legal practice in unauthorized practice of law cases, see, for example, Dauphin County Bar Ass'n v. Mazzacaro, 351 A.2d 229, 232-33 (Pa. 1976).

53. See Sandra E. Purnell, Comment, The Attomey as Mediator-Inherent Conflict of Interest?, 32 UCLA L. REV. 986, 1005-08 (1985).

54. See Marjorie Corman Aaron, Evaluation in Mediation, in DwIGHT GOLANN, MEdIATING LEGAL DISPUTES (1996).

55. Most of us now agree that provision of mediation services does not constitute a lawyerclient relationship. See MODEL RULES OF PROFESSIONAL CONDUCT Rule $2.2 \mathrm{cmt}$. (1983); cf. 1 GeOFrRey C. HazARD \& W. WILLIAM HODES, THE LAW OF LAWYERING 511 (Supp. 1997).

56. See Symposium, The Lawyer's Duties and Liabilities to Third Parties, 37 S. TEX. L. Rev. 957 (1996) (discussing treatment of current changing rules and decisions of liability of lawyers and other fiduciaries to third-party nonclients). 
other legal considerations. ${ }^{57}$ To the extent that good ADR practice depends on drawing from multiple disciplines, we should not cabin the profession within the regulatory dictates of any one profession; yet the question remains, how will we evaluate-and some would say "police"-ADR quality of service? At its most extreme, multi-disciplinary mediators protest that attorneys' narrow disciplinary training puts blinders on how they analyze problems, profoundly limiting the kinds of outcomes that are reached by the parties. ${ }^{58}$

In addition to the disputes about the kind of professional we want to engage in third-party "neutraling" activities, we cannot agree about the content of hybrid roles currently engaged in by recognized third-party neutrals (for example, judges who become enmeshed in brokering settlements ${ }^{59}$, special masters employed by courts to manage discovery, facilitate settlement ${ }^{60}$ or perform other roles, ${ }^{61}$ magistrate judges ${ }^{62}$ and bankruptcy judges, and other court adjuncts. ${ }^{63}$ What rules of behavior should govern such actors-the Judicial Code of Conduct, federal statutes

57. What duty does a non-representative owe a party in a dispute resolution service or meeting? See Colo. REV. STAT. \& 13-22-307 (Supp. 1996) (Colorado Confidentiality Statute) (providing a broad definition of what is included in dispute resolution). Some have suggested a fiduciary-like duty or relationship, see Carrie Menkel-Meadow, The Silences of the Restatement of the Law Governing Lawyers, 11 GEO. J. LEGAL ETHICS (forthcoming 1997) (noting the comments of Professor Nancy Moore), while others have suggested a much more arms-length and distanced relation, see Meyerson, supra note 51 . Are duties of confidentiality different from duties to investigate and research law and give accurate legal opinions in ADR?

58. See Leonard L. Riskin, Mediation and Lawyers, 43 OHIO ST. L.J. 29, 43-48 (1982) (discussing the limited conceptual maps of lawyers and legal approaches to problems); see also DONALD A. SCHON \& MARTIN REIN, FRAME Reflection: TOWARD THE RESOlUTION OF INTRACTABLE POLICY CONTROVERSIES 26-28 (1994) (discussing the ways in which how we frame problems and generate metaphors affects the types of solutions we see).

59. See Susan P. Koniak \& George M. Cohen, Under Cloak of Settlement, 82 VA. L. ReV. $1051,1097-1102$ (1996) (decrying the role of judges in approving class action settlements in consumer, anti-trust, securities, and mass torts cases); Peter H. Schuck, The Role of Judges in Settling Complex Cases: The Agent Orange Example, 53 U. CHI. L. REV. 337, 341-48 (1986) (discussing the role of Judge Weinstein).

60. See In re Joint E. and S. Dists. Asbestos Litig., 737 F. Supp. 735 (E.D.N.Y. \& S.D.N.Y. 1990) (holding that Special Master Kenneth Feinberg did not have conflicts of interest as special master, measured by Judge Weinstein's application of the Judicial Code of Conduct standards applied to special master).

61. See Francis E. McGovern, Toward a Functional Approach for Managing Complex Litigation, 53 U. CHI. L. REV. 440 (1986).

62. See Marie Provine, Settlement Strategies for federal District Judges (1986); CARROLl SERON, THe ROles Of MAGISTRATES: NiNe CASE STUDies (1985); Linda J. Silberman, Masters and Magistrates, Part II: The American Analogue, 50 N.Y.U. L. REV. 1297 (1975).

63. See Daniel J. Bussel, Coalition-Building Through Bankruptcy Creditors' Committees, 43 UCLA L. REV. 1547 (1996). 
for recusals and conflicts of interests, ${ }^{64}$ or their state equivalents? ${ }^{65}$ And how does the entry of private actors into formerly public, third-party neutraling affect how functions are performed and evaluated, such as with the use of repeat-player providers like JAMS/Endispute, the AAA, and other contractually specified third-party neutrals? $?^{66}$

Some of the concerns about which standards to apply to third-party neutrals reflect a growing ambivalence or contradiction in the conception of what constitutes a proper third party. While American legal culture seems to prefer a "neutral"67 who is supposedly impartial, nonpartisan, and objective with respect to the parties and the dispute itself, ${ }^{68}$ some historical forms of ADR prefer engaged, enmeshed, and totally involved third parties to act as arbitrators or mediators. These third parties serve as "wise persons" who know the community, the nature of the dispute, the disputants, or perhaps all three. ${ }^{69}$ There are traces of this desire for a less

64. See, e.g., 28 U.S.C. 8455 (1993).

65. See CAL. CODE OF JUDICIAL CONDUCT Canon 6, \& D (1996) (covering temporary judges, referees, and court-appointed arbitrators).

66. Recently, the National Employment Lawyers Association threatened to boycott particular providers of arbitration services because of its belief that pre-contract selection by repeat player employers in employment contracts was an unethical practice. The boycott was averted when some of the offending agencies agreed to abide by a statement of due process protections in the manner in which employment arbitrations were to be conducted. See Lisa B. Bingham, Emerging Due Process Concems in Employment Arbitration: A Look at Actual Cases, 47 LAB. L.J. 108 (1996) (publishing the Due Process Protocol at Appendix A and reporting on an empirical study of AAA employment arbitration cases processed under two sets of rules); National Employment Lawyers Will Boycott ADR Providers, 6 WORLD ARB. \& MEDIATION ReP. 240 (1995); Arnold M. Zack, Arbitration as a Tool to Unclog Govemment and the Judiciary: The Due Process Protocol as an Intemational Model, 7 WORLD ARB. \& MEDIATION REP. 10 (1995-1996); Arnold M. Zack, Cole Decision Shows Need for the National Due Process Protocol, DISP. RESOL. MAG., Summer 1997, at 23; see also Stephen J. Ware, Employment Arbitration and Voluntary Consent, 25 HOFSTRA L. REV. 83 (1996). In a recent case, JAMS/Endispute refused to arbitrate a pre-dispute contract arbitration matter in an employment dispute that waived statutory rights and remedies because the clause violated its own internal protocol. See Great Western Mortgage Corp. v. Peacock, 110 F.3d. 222 (3d Cir. 1997). The court determined the dispute was arbitrable anyway. In a notorious case reported in the Los Angeles Times, an agreement to sell real estate contained a provision appointing a particular provider of arbitration services, waiving any claim of conflict of interest. See Myron Levin, Cavear: Know Your Arbitrator, L.A. TiMES, Jan. 19, 1997, at D1.

67. The standard phrase used to describe the third-party function in ADR circles is "thirdparty neutral," assuming that the third party is neutral and conjuring up all of the attributes of the objective, distanced "judge" in our legal system.

68. This is why many commentators choose to import wholesale the requirements of the Judicial Code of Conduct or judicial standards of recusal or conflicts of interest or even the more complex lawyer rules for conflicts of interest. See MODEL RULES OF PROFESSIONAL CONDUCT Rules 1.7-1.12 (1983). The Model Rules are used by analogy in most conflicts-of-interest cases involving ADR. See infra text accompanying notes 208-218.

69. See, for example, the discussion of community elders as mediators in SHAPIRO, supra note 19, at 6 (the "big man"), and the use of known community mediators in religious, ethnic, and business communities in AUERBACH, supra note 31. 
neutral, but more known and involved third party in labor arbitration (in which parties seek someone who knows the "law of the shop"79, and in commercial arbitration (in which parties seek those who are familiar with the unwritten practices and rules of the industry ${ }^{71}$ ). In many current areas of ADR, parties request knowledgeable "experts" as third-party arbitrators and mediators to ensure knowledge, competency, and efficiency of dispute resolution facilitation and, in some sense, to echo the historical desires for a "wise elder."72 Thus, parties may differ about whether they want engaged and interested third parties in dispute resolution or more neutral and detached dispute resolvers. These conflicting desires, choices, and possibilities present a host of difficulties for regulation and for stating the norms of a new profession.

Finally, as we consider who should conduct ADR, interesting questions have been raised concerning whether attorneys further dispute resolution and settlement by serving as agents of cooperation, ${ }^{73}$ or whether they damage and hinder dispute resolution processes, ${ }^{74}$ causing some to argue that lawyers' roles should be separated as litigators or settlers. ${ }^{75}$ To the extent that the advocate's role is sufficiently different from the problem-

70. See Reginald Alleyne, Statutory Discrimination Claims: Rights "Waived" and Lost in the Arbitration Forum, 13 HofsTRA LAB. L.J. 381 (1996); Robert A. Gorman, The Gilmer Decision and the Private Arbitration of Public Law Disputes, 1995 U. ILL. L. REv. 635, 654-60 (1995).

71. See Lisa Bernstein, Opting Out of the Legal System: Extralegal Contractual Relations in the Diamond Industry, 21 J. LEGAL STUD. 115 (1992); Soia Mentschikoff, Commercial Arbitration, 61 COLUM. L. REV. 846, 852-53 (1961); see also Stewart Macaulay, Non-Contractual Relations in Business: A Preliminary Study, 28 AM. SOC. REV. 55 (1963) (discussing preferences of business people to resolve commercial disputes on their own).

72. Taken at its most literal, there have been recent challenges to the use of mostly "white, male elders" as arbitrators in certain disputes, such as employment disputes in the securities industry. See Alleyne, supra note 70; see also Olson v. American Arbitration Ass'n, Inc., 876 F. Supp. 850, 852 (N.D. Tex. 1995), aff'd, 71 F.3d. 877 (5th Cir. 1995) (rejecting a claim by women sex discrimination claimants that $A A A$ arbitrators were biased because they were predominantly older white males). Whether a desire for expertise and wise elders serves as a pretext for choosing certain kinds of arbitrators or mediators remains an interesting question.

73. See Rachel Croson \& Robert Mnookin, Does Disputing Through Agents Enhance Cooperation? Experimental Evidence (Working Paper, Harvard Law School Olin Foundation) (1996); Ronald J. Gilson \& Robert H. Mnookin, Disputing Through Agents: Cooperation and Conflict Between Lawyers in Litigation, 94 COLUM. L. REV. 509 (1994).

74. See Hubert J. O'GORMAN, LAWYers AND Matrimonial CASES (1963); Carrie Menkel-Meadow, supra note 6; Menkel-Meadow, supra note 14; Marguerite S. Millhauser, Gladiators and Conciliators: ADR: A Law Firm Staple, B. LEADER, Sept.-Oct. 1988, at 20; Marguerite Millhauser, The Unspoken Resistance to Altemative Dispute Resolution, 3 Negotiation J. 29, 31-32 (1987).

75. See Roger Fisher, What About Negotiation as a Specially?, 69 A.B.A. J. 1221, 1223 (1983). 
solver's role, ${ }^{76}$ we must consider whether different tracks of education, practice, and ethical regulation may be required for these different roles. ${ }^{77}$ Can we train lawyers to be resilient and versatile enough to be creative and synthetic, ${ }^{78}$ as well as analytic and critical? Can different models of candor $^{79}$ be useful, required, and regulated for different functions performed by lawyers as dispute resolution representatives? How will the lawyer's role as dispute resolution representative ${ }^{80}$ differ from her role as advocate or as third-party neutral? Different roles are dictated in part by the lawyer's conception of the purpose of the ADR proceeding, and by each process' folklore, structure, organizational context, and location.

\section{What PROCESSES CONSTITUTE ADR?}

Defining what processes constitute ADR has always been difficult. Both new casebooks and older articles are filled with taxonomies ${ }^{81}$ of dispute resolution processes, ranging from spectrums that include characteristic variations along dimensions of: the numbers of parties (single self-help, dyadic negotiations, two-party mediation, multi-party disputes); the role of the third-party neutral (facilitator, conciliator, decider); voluntariness;

76. Compare the zealous advocate of the MODEL CODE OF PROFESSIONAL RESPONSIBILTTY Canon 7 (1980), with the more modern duty of diligence, MODEL RULES OF PrOFESSIONAL CONDUCT Rule 1.3 (1983).

77. See Carrie Menkel-Meadow, Ethics in Dispute Resolution: New Issues, No Answers from the Adversary Conception of Lawyers' Responsibilities, 38 S. TEX. L. REV. 1 (1997).

78. For illustrations of different kinds of problem-solving strategies than those commonly used by lawyers, see JAMES L. ADAMS, THE CARE AND FEEDING OF IDEAS (1986); JAMES L. ADAMS, CONCEPTUAL BLOCKBUSTING (3d ed. 1986); MARTIN GARDNER, AHA! INSIGHT (1978); see also Carrie Menkel-Meadow, To Solve Problems, Not Make Them: Integrating ADR in the Law School Curriculum, 46 SMU L. REv. 1995 (1993).

79. See MODEL RULES OF PROFESSIONAL CONDUCT Rule 3.3 (1983) (concerning lawyers' obligations to be candid to tribunals by requiring reporting of adverse legal authority). What about candor to other parties in solution-seeking ADR processes rather than advocates' adversarial in-court behavior? When must a lawyer be candid in an ADR tribunal? (Does it matter if the tribunal is in the courthouse or in a lawyer's private office?)

80. For new efforts to teach lawyers to be advocates in sertings in which we all thought they would be less adversarial and more problem-solving in approach, see JOHN COOLEY \& STEPHEN LUBET, ARBITRATION ADVOCACY (1996) (describing a more conventional use of advocacy skills); JOHN W. COOley, Mediation ADVOCACy (1996); ERIC Galton, A GUIDE for Mediation REPRESENTATION (1994).

81. See Alternative Dispute Resolution: StRATEgies for law and Business (E. Wendy Trachte-Huber $\&$ Stephen K. Huber eds., 1996); STEPHEN B. GOLDBERG ET AL., DISPUTE RESOLUTION (2d ed. 1994); JOHN S. MURRAY ET AL., PROCESSES OF DISPUTE RESOLUTION: THE ROLE OF LAWYERS (2d ed. 1996); The ABCs of ADR: A Dispute Resolution Glossary, 13 ALTERNATIVES 147-51 (1995). 
finality (binding and nonbinding processes); and primary (negotiation, mediation, or adjudication) or hybrid (med-arb, mini-trials, summary jury trials) processes; as well as public versus private location of the process. In addition, modern formulations of the variations in ADR practice now include ADR ex ante (pre-dispute, as in a contract providing the dispute resolution devices to be used in the event of dispute) and ADR post hoc (either chosen after the dispute has already occurred through a lawsuit and referral to court or private ADR fora, or simply when the parties choose some form of ADR as a dispute "ripens," but before a formal lawsuit). ${ }^{82}$ In a new phrasing of old differences, some commentators have begun to separate decision-oriented ADR (arbitration or evaluative mediation) from settlement-seeking ADR (facilitative mediation). ${ }^{83}$

As ADR proliferates into these variations, the wide variety of practices within any particular taxonomy threatens to destroy the categorical integrity of any description, making client counseling, ethics, and regulation quite difficult. ${ }^{84}$ I will describe some of the variations to illustrate the kinds of dilemmas that occur when processes do not mean the same thing to all people. . $^{85}$

82. For an important description of the social processes that construct whether a dispute will ripen from a "perceived injurious experience" to a lawsuit, see William L.F. Felstiner et al., The Emergence and Transformation of Disputes: Naming, Blaming, and Claiming . .., 15 L. \& SOC'Y REV. 631 (1980-1981); see also Carrie Menkel-Meadow, The Transformation of Disputes by Lawyers: What the Dispute Paradigm Does and Does Not Tell Us, 1985 MO. J. DISP. RESOL. 25.

83. See Stempel, supra note 41.

84. A series of recent ethics decisions in a number of states now require lawyers to inform their clients of offers to mediate or seek settlement. See Arthur Garwin, Show Me the Offer, A.B.A. J., June 1997, at 84 (reporting on ethics opinions from Pennsylvania (Opinion 90-125)); see also Jackson v. Philadelphia Hous. Auth., 858 F. Supp. 464 (E.D. Pa. 1994); Kan. Bar Ass'n Comm. on Ethics-Advisory Services, Op. 94-01 (1994); Mich. State Bar Comm. on Profl and Judicial Ethics, Informal Op. RI-255 and RI-262 (going further to suggest that counsel has an obligation to suggest alternatives to client "when alternative is reasonable course of action to further client's interest or if the lawyer has any reason to think the client would find the alternative desirable").

85. Indeed, most of us toiling in the field continue to find it startling that with all of the basic descriptions available, lawyers as well as parties continue to confuse mediation (facilitation) with arbitration (adjudication-like decision making) and certainly do not often understand most of the refinements of the secondary and hybrid processes and the debates that we ADR professionals are having about what is appropriate in each. For me, this raises the issue of how much process description should be available when parties choose ADR processes and when they select particular providers. The CPR-Georgetown Commission on Ethics and Standards in ADR is currently drafting model disclosure statements for providers. 
The current, most heated debate concerns the question whether mediation is facilitative or evaluative or both. In a series of debates that have appeared in the columns of dispute resolution journals, "pure" mediation advocates suggest that mediation involves no more than a third-party neutral facilitating communication between parties, never evaluating or judging cases. ${ }^{86}$ In actual practice, many mediators' functions vary from facilitating communication, to probing the parties' own thinking about the strengths and weaknesses of their cases, to neutral evaluation of the mer${ }^{i t s}{ }^{87}$ to prediction of how courts will decide cases, to forms that include suggesting solutions (with or without the use of shuttle diplomacy) or approaching decision-like arbitration. These definitional differences matter because, while they may begin as behavioral or technique differences in how ADR is practiced, they derive from different philosophies of ADR and its purposes, implicating very important ethical concerns. ${ }^{88}$

Even within the "pure" mediation camp, there are debates concerning whether it is appropriate to be a "settlement-seeking" problemsolver rather than one who "transforms" the parties to appreciate each other and them-

86. See Aaron, supra note 54; John Bickerman, Evaluative Mediator Responds, 14 ALTERNATIVES (1996); J. Michael Keating, Mediating in the Dance for Dollars, 14 ALTERNATIVES (1996); Kimberlee K. Kovach \& Lela P. Love, "Evaluative" Mediation is an Oxymoron, 14 ALTERNATIVES (1996); Kimberlee K. Kovach, What is Real Mediation and Who Should Decide?, 3 DISP. RESOL. MAG. 5 (1996); Leonard Riskin, Understanding Mediators' Orientations, Strategies and Techniques: A Grid for the Perplexed, 1 HARV. NEG. REV. 7 (1996); see also James J. Alfini, Evaluative Versus Facilitative Mediation: A Discussion, 24 FLA. ST. U. L. REV. 919 (1997); Jeffrey W. Stempel, Beyond Formalism and False Dichotomies: The Need for Institutionalizing a Flexible Concept of the Mediator's Role, 24 FLA. ST. U. L. REV. 949 (1997); Symposium, Mediation, 24 FLA. ST. U. L. REV. 800 (1997).

87. Many courts use early neutral evaluation as a formal way of combining evaluative and mediative techniques. See Rosenberg \& Folberg, supra note 23.

88. The Joint Standards for the Conduct of Mediators, written by the American Bar Association, American Arbitration Association, and the Society for Professionals in Dispute Resolution, for example, suggests that mediators should never evaluate cases. See infra Part VI. This, in my view, flies in the face of actual practice, both in large-scale commercial and corporate mediation in which mediators are often chosen precisely because of their substantive expertise, see JAMES FREUND, THE NEUTRAL NEgOTIATOR: WHY AND HOW MEDIATION CAN WORK TO RESOlVE DOLLAR DISPUTES (1994), and in court programs in which the parties and the lawyers ask the mediators to "reality test" by giving them a sense of what the going rate is, particularly in torts and contracts cases. Thus, the ethical and practice concerns about what is or is not appropriate to say or do in a separate caucus session will matter greatly depending on what one's orientation is to the appropriateness of evaluative behavior in mediation. Denying that it exists or defining it away will not likely be successful over the long run. 
selves. ${ }^{89}$ Others argue that such a focus on the parties' underlying psychological needs is inappropriate "therapy" in the context of bargaining strategies used for settling disputes in the legal arena. ${ }^{90}$ In fact, mediators vary their techniques based on their own disciplinary backgrounds, the contexts in which they work, and the urgency of the problems with which they are dealing. ${ }^{91}$ Whether we can construct a "meta" theory of mediation that is protean enough to include all variations remains to be seen.

At the other end of the spectrum, some arbitration practices have moved closer to mediation, and one often hears of arbitrators resisting their adjudicative role in order to attempt settlement (before, during, and even after arbitration hearings). Med-arb formally recognizes this hybrid, more complex form of practice, such as the California practice of having family court conciliators recommend results to judges when they have failed at mediation in some counties. ${ }^{92}$ Indeed, practitioners of arbitration still debate whether arbitration is a settlement device that ensures earlier trial dates and forces the parties to focus on their cases or an adjudication process (providing the satisfaction of a third-party hearing and ruling, with a

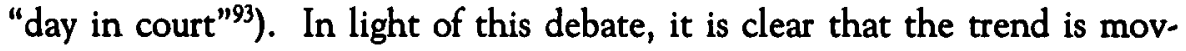
ing away from arbitration and toward more flexible, mediative approaches, ${ }^{94}$ perhaps because of the greater party control involved and the possibility of more responsive and individually crafted outcomes (as well as the nonbinding quality of mediation).

89. This is the recognition and empowerment model of mediation advocated by Robert Bush and Joseph Folger. See BUSH \& FOLGER, supra note 2, at 81.

90. See Susan S. Silbey \& Sally E. Merry, Mediator Settlement Strategies, 8 LAW \& POL'Y 7, 19 (1986); Susan S. Silbey \& Austin Sarat, Dispute Processing in Law and Legal Scholarship: From Institutional Critique to the Reconstruction of the Juridical Subject, 66 DENV. U. L. REV. 437 (1989).

91. For a riveting review of different mediator styles in contexts ranging from labor relations, to international disputes, to public housing project violence, to court cases, to public policy issues, see WhEN TALK WORKS: Profiles OF MEDIATORS (Deborah M. Kolb et al. eds., 1994). For my own take on whether a unified theory of mediation practice is possible, given these contextual variations, see Carrie Menkel-Meadow, The Many Ways of Mediation: The Transformation of Traditions, Ideologies, Paradigms and Practices, 11 NEGOTIATION J. 217 (1995).

92. See CAL. FAM. CODE $\S 3183$ (Deering 1994 \& Supp. 1997). Many of us find this mixed role particularly troubling because mediators promise confidentiality and encourage candid revelation of potentially damaging facts from litigants, but the mediator can subsequently use this information against the litigant in a recommendation to the court. See Grillo, supra note 7, at 1555.

93. See Barbara S. Meierhoefer, Court-ANneXed ARbItration IN Ten District COURTS (1990); Deborah R. Hensler, Court-Ordered Arbitration: An Altemative View, 1990 U. CHI. LEGAL F. 399; E. Allan Lind et al., In the Eye of the Beholder: Tort Litigants' Evaluations of Their Experiences in the Civil Justice System, 24 L. \& SOC'Y REV. 953 (1990).

94. See PLAPINGER \& STIENSTRA, supra note 23. 
Academics, practitioners, and courts are currently scrutinizing arbitration as courts increasingly sustain its use in various fields such as consumer, banking, health, employment, securities, and franchise contracts, ${ }^{95}$ against claims of unconscionability, violation of federal or state law, or constitutional rights. ${ }^{96}$ As the United States and California Supreme Courts continue to treat arbitration as the dispute resolution method of choice, there are some small signs of counter-winds blowing in the lower courts as they review the unfairness of subjecting unsuspecting employees or consumers to arbitration clauses they did not understand when they signed their contracts or accepted their employee personnel manual. ${ }^{97}$ Thus, while arbitration is gaining court approval and con-

95. See, e.g., Doctor's Assocs., Inc. v. Casarotto, 116 S. Ct. 1652, 1657 (1996) (holding an arbitration clause in franchise agreement enforceable despite a state statute voiding arbitration clauses not in large print, pursuant to preemption of Federal Arbitration Act); Allied-Bruce Terminex Co. v. Dobson, 115 S. Ct. 834, 838 (1995) (sustaining arbitration clause under the Federal Arbitration Act in interpreting interstate commerce); Mastrobuono v. Shearson Lehman Hutton, Inc., 514 U.S. 52, 59-60 (1995) (holding that securities arbitration clauses allow arbitration panels to award punitive damages under the Federal Arbitration Act, regardless of state law); Gilmer v. Interstate/Johnson Lane Corp., 500 U.S. 20 (1991) (holding that an arbitration agreement in a securities representative registration document requires claim brought under the Age Discrimination in Employment Act to be subject to arbitration); Rodriguez de Quijas v. Shearson/American Express, Inc., 490 U.S. 477 (1989) (holding that a claim brought under the Securities Act of 1933 is not required to proceed in a judicial forum when the parties have an arbitration clause in their agreement); Mitsubishi Motors Corp. v. Soler Chrysler-Plymouth, Inc., 473 U.S. 614 (1985) (holding that an arbitration clause in a distribution and sales agreement is enforceable); Badie v. Bank of Am., No. 944916, 1994 WL 660730 (Cal. App. Dep't Super. Ct. Aug. 18, 1994) (allowing the addition of an ADR clause to bank's contract with customers). See generally Barry Meier, In Fine Print, Customers Lose Ability to Sue, N.Y. TIMES, Mar. 10, 1997, at $\mathrm{Al}$.

96. For some of the recent scholarly criticisms of pre-dispute contract arbitration, see Alleyne, supra note 70; Carrington \& Haagen, supra note 47; Gorman, supra note 70; Jean R. Sternlight, Panacea or Corporate Tool?: Debunking the Supreme Court's Preference for Binding Arbitration, 74 WASH. U. L.Q. 637 (1996); Stephen J. Ware, Arbitration and Unconscionability After Doctor's Associates, Inc. v. Casarotto, 31 WAKE FOREST L. REV. 1001 (1996).

97. See Engalla v. Permanente Med. Group, 64 Cal. Rptr. $2 d 843$ (1997), rev'g 43 Cal. Rptr. $2 \mathrm{~d} 621$ (1995) (holding that a court may deny a petition to compel arbitration in which petitioner fraudulently induces agreement to arbitrate dispute presumption in favor of arbitration); see also Prudential Ins. Co. v. Lai, 42 F.3d 1299 (9th Cir. 1994), cert. denied, 116 S. Ct. 61 (1995) (holding that a compulsory arbitration clause in an employment setting was not voluntarily agreed to by party and not enforceable). The Seventh Circuit has recently declined to enforce an arbitration clause in a collective bargaining agreement, under FAA requirements, in two employment discrimination cases in which it held that statutory discrimination claims were perhaps broader than contractual ones and that recent amendments to Title VII permitting trial by jury in such claims demonstrated the importance of a litigant's choice of forum in statutory rights cases. See Pryner v. Tractor Supply Co., 109 F.3d 354, 363 (7th Cir. 1997). Writing for the majority, Chief Justice Posner opined, "We are not holding that workers' statutory rights are never arbitrable. They are arbitrable if the worker consents to have them arbitrated." Id. Judge Posner identified the potential conflict of interest between the employee and the union who is the actual signatory to the collective bargaining agreement, and in this context accepted the argument that arbi- 
tractual implementation by those who write form contracts, it is also fostering an anti-ADR climate by promoting nonconsensual, even coercive, forms of dispute resolution. Although the controversial uses of arbitration in particular contexts (such as in form or adhesion contracts ${ }^{98}$ ) must be met on their own merits, those who seek to preserve the desirable aspects of arbitration-its efficiency and possibility of a fair hearing-will either have to reform the processes to meet party objections ${ }^{99}$ or face continuing legal battles and uncertainty about the sustainability of such clauses.

Concerns about misunderstandings or misuse of particular ADR processes are compounded when differences of behavior, strategy, or techniques within the processes may be necessary to accomplish different ends. Arbitration and evaluative mediation may suggest more traditional adversarial behavior, but facilitative mediation, for example, requires both the mediator and party representatives to be more open, candid, creative, and solution-seeking. Different behaviors may be necessary in different ADR processes. For example, judges and others extol the virtues of some forms of ADR in "narrowing the issues for trial," such as in mandatory

tration was not necessarily agreed to by the employee. Thus, conflicts continue in the circuit courts of appeal with respect to the enforceability of arbitration clauses in both employment and collective bargaining agreements, at least for statutory rights. The Pryner decision adopted the view enunciated in Alexander v. Gardner-Denver Co., 415 U.S. 36 (1974), taking the position that statutory discrimination claims cannot be allocated exclusively to arbitration, rather than the possible interpretation of Gilmer that they can. See also Katherine Van Wezel Stone, Mandatory Arbitration of Individual Employment Rights: The Yellow Dog Contract of the 1990s, 73 DENV. U. L. REV. 1017 (1996). In a recent case the D.C. Circuit Court of Appeals has sustained a pre-dispute employment arbitration clause, but only by requiring the employer to pay the costs of the arbitration and by reminding the arbitrator that law must be properly applied in employment arbitrations. See Cole v. Burns Int'l Sec. Servs., 105 F.3d 1465 (D.C. Cir. 1997).

98. See Todd D. Rakoff, Contracts of Adhesion: An Essay on Reconstruction, 96 HARV. L. REV. 1174 (1983); see also Edwin W. Patterson, The Delivery of $a$ Life-Insurance Policy, 33 HARV. L. REV. 198 (1919) (providing the first description of an adhesion contract). The recent decision of the California Supreme Court in Engalla did not find the arbitration clause itself unconscionable; rather, it questioned the "gap between its contractual representations and the actual workings of the arbitration program." $64 \mathrm{Cal}$. Rptr. $2 \mathrm{~d}$ at 866.

99. Wayne Outten, Esq., of New York, and former president of the National Employment Lawyers Association, has called pre-dispute mandatory arbitration in employment contracts unconscionable "cram-down" arbitration, although he continues to support consensual mediation. Wayne Outten, Comments at the CPR Winter Meeting on Issues in Employment ADR Jan. 1996); see Bingham, supra note 66, at 122 (reprinting as Appendix A the Due Process Protocol for Arbitration of Statutory Employment Disputes, as signed by the AAA, ABA Labor and Employment Section, Federal Mediation and Conciliation Service, National Employment Lawyers Association, and ACLU Workplace Committee). 
settlement conferences, ${ }^{100}$ early neutral evaluation and arbitration, and in some cases, mediation. However, conflict resolution theory has long demonstrated that settlement becomes more likely not by narrowing issues, but by expanding issues, so that more trade-offs or Pareto-optimal solutions can be found. ${ }^{101}$ Thus, strategies that work well for one form of ADR practice may actually be counterproductive for others. Courts, for example, must consider whether they need one process and one set of third-party neutrals for settlement possibilities (for creative option generation and trade-off seeking communication) and another process with a different set of skilled neutrals to be utilized for adjudication (arbitration) or case management (discovery and trial-setting issues), as in settlement conferences or early neutral evaluations. ${ }^{102}$

Another "hot button" in ADR practice involves the merits of mandatory versus voluntary assignment to ADR processes. In a series of debates ranging from the halls of Congress, ${ }^{103}$ to state legislatures, to individual

100. Maurice Rosenberg, The Pretrial Conference and Effective Justice: A CONTROLled Test IN PERSONAl InJURy LiTIGation (1964); Carrie Menkel-Meadow, For and Against Settlement: The Uses and Abuses of the Mandatory Settlement Conference, 33 UCLA L. REV. 485 (1985).

101. See, e.g., RAIfFA, supra note 3, at 14; I. WILLIAM ZARTMAN \& MAUREEN R. BERMAN, THE PRACTICAL NEGOTIATOR 13-14, 174-76 (1982); Menkel-Meadow, supra note 6 (arguing from the principle enunciated in the work of George Homans, Social Behavior: Its Elementary Forms, that people value things differently and thus trade-offs are increased when parties seek complementary and not competing preferences). In political and philosophical fora this is often called "log-rolling." See Martin P. Golding, The Nature of Compromise, in NOMOS: COMPROMISE IN ETHICS, LAW, AND POLITICS J. Roland Pennock \& John W. Chapman eds., 1979).

102. Courts, like the Northern District of California federal court, employ "multi-option" menus of ADR choices to fit different case types and different stages of cases, with ADR counseling provided by a professional ADR staff. See PLAPINGER \& STIENSTRA, supra note 23; Stephanie Smith, Obtaining Maximum Benefit from ADR Phone Conversations, Ass'N BuS. TRIAL L. REP., Mar. 1995, at 1. For a review of some of the issues facing courts that refer cases to ADR, see Carrie Menkel-Meadow, Judicial Referral to ADR: Issues and Problems Faced by Judges, FJC DIRECTIONS, Dec. 1994, at 8.

103. Congressional debates covered the issue of whether court-annexed arbitration should be mandatory, both within individual courts and throughout the federal system. See Wayne D. Brazil, In Support of Nonbinding, Presumptively Mandatory Arbitration for Modest-Sized Contract and Tort Cases in Some Federal Courts, FJC DIRECTIONS, Dec. 1994, at 14 (providing arguments for and against mandatory arbitration); G. Thomas Eisele, The Case Against Mandatory Court-Annexed ADR Programs, 75 JUDICATURE 34 (1991); William R. Wilson, Jr., In Opposition to Statutory or Local Rule Amendments to the Seventh Amendment, in Opposition to Mandatory Arbitration in Any Case, FJC DiRECTIONS, Dec. 1994, at 15; see also Federal Courts Improvement Act of 1994: Hearing on H.R. 4357 Before the Subcomm. on Intellectual Property and Judicial Admin., 103d Cong. 53 
courts, ${ }^{104}$ fervent proponents argue either for or against mandatory programs. As with so many $A D R$ issues, the lines dividing the definitions are less than clear. Mandatory programs often mean only that the parties must attempt some nonbinding process but retain all constitutional rights and may return for a full trial by jury if they so desire. ${ }^{105}$ In other cases, certain forms of ADR are "presumptively mandatory," 106 meaning that parties may request assignment out of $A D R$ for appropriate reasons or that certain kinds of cases may be exempt from ADR referrals. ${ }^{107}$ Some ADR practitioners have been disturbed by the mislabeled, oxymoronic use of the term "mandatory mediation" used in the Michigan state court system in which a panel of lawyers hears presentations on the merits and recommends a particular monetary amount for settlement. ${ }^{108}$ The term "mandatory mediation" disturbs virtually all mediation practitioners because of the commitment to self-determination and voluntariness as one of the core features of a process that was designed to be totally consensual. To the extent that courts refer to "mandatory" programs as an indication of an obligation to participate, rather than an obligation to agree, courts might need to clarify these terms and meanings to assure the acceptance and legitimacy of these programs.

While the term "mandatory" may mean only that one must attend some form of ADR in good faith, what constitutes compliance with this requirement remains unclear and is currently being tested in the courts. ${ }^{109}$ Some fear that skilled adversarialists will use mandatory attendance at ADR

(1994) (testimony of the Honorable Deanell Reece Tacha and the Honorable Rya W. Zobel on behalf of the Judicial Conference) (testifying in support of continuing authorization of voluntary arbitration programs).

104. Judicial debates concerned promulgating local rules and establishing court programs. See PLAPINGER \& STIENSTRA, supra note 23.

105. See Dwight Golann, Making Alternative Dispute Resolution Mandatory: The Constitutional Issues, 68 OR. L. REV. 487 (1989); Lucy V. Katz, Compulsory Alternative Dispute Resolution and Voluntarism: Two-Headed Monster or Two Sides of the Coin?, 1993 J. DiSP. RESOL. 1.

106. Such presumptively mandatory ADR includes, for example, the statutorily authorized mandatory court-annexed arbitration programs in some federal and state courts.

107. The most common exemptions from mandatory arbitration or other ADR programs include civil rights and constitutional claims, prisoner claims, and social security cases. See, e.g., E.D. PA. R. 53.2 (as amended July 1, 1995). Some courts exempt, while others invite, such cases as bankruptcy claims. Most courts exempt cases involving pro se litigants, but there is growing discussion about experimenting with alternative forms of case processing even in these exempt cases.

108. See Kathy L. Shuart, Federal Judiclal Ctr., The Wayne Countr Mediation PROGRAM IN THE EASTERN DISTRICT OF MICHIGAN (1984).

109. See, e.g., Edward F. Sherman, Court-Mandated Alternative Dispute Resolution: What Form of Participation Should be Required?, 46 SMU L. REV. 2079 (1993); see also G. Heileman Brewing Co. v. Joseph Oat Corp. 871 F.2d 648 (7th Cir. 1989) (en banc). 
proceedings simply to prepare or discover information from the other side, without any real commitment to the process. ${ }^{110}$ To the extent that court programs remain nonbinding and subject to constitutional rights to trial de novo, ${ }^{11}$ mandatory participation does not bind anyone to any particular outcome. Thus, mandatory participation must always be separate from the consideration of whether a particular ADR process is binding or nonbinding, either by party choice or court rule.

My own views on this crucial topic have changed over the years, perhaps due to my own experience as a mediator and trainer in both public and private programs. Whereas 1 once thought that participation in ADR of any kind should be purely voluntary as part of the necessary commitment and motivation to participate in real problem solving, I now think the educative functions of requiring lawyers and parties to at least consider some form of dispute settlement procedure before trial is worth the effort. As I contrast the requirement to "meet and confer" over the best possible way to resolve a dispute ${ }^{12}$ with the requirements of many jurisdictions that litigation can be instituted only after a "demand letter" has been sent, it seems appropriate to me to seek some peaceful means of dispute resolution after the opening adversarial salvo has been fired. In my experience as a third-party neutral, even the most vociferous adversarialist discovers some opportunities for exploring differences and possible solutions in settings that are more open and flexible than trial proceedings, yet more structured and protected than dyadic, lawyer-led negotiations. Thus, to the extent that some forms of ADR prompt attorneys and disputants to consider other ways of solving legal problems, I now favor "presumptively mandatory" participation in ADR, so long as parties may "opt out" with good cause shown. As I will discuss more fully below, I think that public, state-ordered, and structured ADR may help facilitate this educative func-

110. See Carrie Menkel-Meadow, Pursuing Settlement in an Adversary Culture: A Tale of Innovation Co-Opted or "The Law of ADR," 19 FLA. ST. U. L. REV. 1, 17 (1991); Stempel, supra note 41.

111. Some, like Lisa Bernstein, supra note 10, have argued that the right to appeal for a trial de novo after a court-imposed arbitration adds another layer of cost to proceedings and thus disadvantages less well-endowed litigants and may economically "chill" such trial rights. In my own evaluation of at least one court's program, I found no evidence of this phenomenon: poor litigants could use in forma pauperis protections for appeal deposits (the only fee was the arbitrators' fees if the litigant did worse at trial than at arbitration), and "poorer" litigants were either in exempt categories of cases (for example, civil rights and social security) or had attorneys who were paid on a contingent fee basis. See CARRIE MENKEL-MEADOW, U.S. DIST. COURT FOR THE E. DisT. Of PA., ARBITRATION COMMITTEE REPORT (Feb. 21, 1997) (draft report, on file with author).

112. This is required in at least some districts, pursuant to local practices under Rule 16 of the Federal Rules of Civil Procedure pertaining to pretrial conferences. 
tion for the legal profession, provided it is well-monitored, evaluated, and does not abuse the parties or burden their exercise of other legal rights. ${ }^{113}$ In part because many conventional attorneys still believe it shows weakness to suggest $A D R$ or settlement talks, counter-incentives ${ }^{114}$ may be necessary to change the legal culture. ${ }^{115}$

The "mandatory" issue becomes more complicated when we move to the private sector. Though much of the debate about mandates in ADR has focused on the public sector, in fact, mandatory ADR is now far more common in pre-dispute compulsory arbitration clauses. ${ }^{116}$ Despite the rulings of the United States Supreme Court and many state courts sustaining the use of pre-dispute contract allocations to arbitration, the scholarly commentary and some consumer advocacy clearly runs counter to this precedent, and I predict that some courts will begin to take a closer look at some forms of mandated private ADR. Commentators have suggested a number of different challenges to mandated arbitration, especially when it is either binding or subject to the very limited review conditions allowed under the Federal Arbitration Act. ${ }^{117}$ Although at least one commentator has argued that ADR's private replacement of the public justice system will lead courts to recognize $A D R$ as state action requiring due process pro-

113. What is wrong with some innovation and change in the formal court system in order to attempt to educate parties about other ways of disputing? As at least one commentator has pointed out, virtually all of our institutions (medical, educational, business) would be unrecognizable to a visitor from the nineteenth century-except our legal system, which looks remarkably the same. Is the legal system resistant to change for good reasons (because it is so fair, good, efficient, just) or for bad (stubborn and conservative resistance to change)? See Rosalie Silberman Abella, The Changes Lawyers Will Face: A Response to 'Changing Demographics,' 23 L. SOC'Y GAZETTE 149 (1989) (address delivered to the Law Society of Upper Canada Benchers' Retreat); Rosalie Silberman Abella, The Civil Litigation Process Under Siege: Roscoe Pound Redux, 28 L. SOC'Y GAZETTE 213 (1994).

114. For several important arguments that mediation makes economic sense and should serve as its own incentive to achieve efficient and rational solutions to legal problems, see Jennifer Gerarda Brown \& Ian Ayres, Economic Rationales for Mediation, 80 VA. L. REV. 323 (1994) (exploring, among other rationales, how mediators correct for information asymmetries to produce better solutions than if parties were left on their own). For several other elaborations of these arguments, see Ian Ayres \& Barry J. Nalebuff, Common Knowledge as a Barrier to Negotiation, 44 UCLA L. REV. 1631 (1997), and Jennifer Gerarda Brown, The Role of Hope in Negotiation, 44 UCLA L. REV. 1661 (1997).

115. As noted, supra note 84 , one form of counter-incentive might be new ethical rules requiring lawyers to pursue ADR counseling with their clients. See COLO. RULES OF PROFESSIONAL CONDUCT Rule 2.1 (1996). As an ethicist, however, I am not sanguine about how minimalist disciplinary enforcement will fare in this area (malpractice and liability litigation might be better forms of discipline). Court requirements are another form of incentive that could have spill-over effects in nonmandated cases.

116. See supra text accompanying notes 94-99.

117. See U.S.C. $\$ 10$ (1994) (limiting review conditions to fraud, corruption, partiality, or arbitrator misconduct). 
tections, ${ }^{118}$ I think such a result is unlikely. Parties have always been free to resolve differences among themselves, and in our party-initiated adversary system, ${ }^{119}$ courts are likely to defer to party choice and initiative, especially when it coincides with judicial interest in case load reduction. ${ }^{120}$

To the extent that attacks on compulsory arbitration are going to be successful, they will likely rest either on the general contract doctrines of unconscionability, "failure to form a contract on this term," or fraud. Indeed, the ruling in Doctors' Associates v. Casarotto ${ }^{121}$ makes clear that virtually any attempt by a state to regulate arbitration must be grounded on principles generally applicable to all contracts. To the extent that courts like the Ninth Circuit in Prudential v. Lail ${ }^{122}$ have begun to recognize the absence of real assent to compulsory arbitration terms in form contracts or employee manuals, conventional contract doctrine will most likely cure the ills of mandated arbitration. There is some doctrinal integrity to this reliance on traditional contract principles. While I do not disagree that procedures that influence people to waive their "due process" right to litigate may sound like a private encumbrance on important public and constitutionally guaranteed rights, this "waiver" comes from a presumed private contract and it is that contract (as a bar to the exercise of one's legal rights) that stands in the way and needs to be voided to guarantee full expression of one's legal rights. Thus, if the contract is not formed properly or is otherwise void, voidable, invalid, or unlawful, one need not reach the more difficult state action claim. ${ }^{123}$ Indeed, if an "ADR ideology" stands for consensual dispute resolution, ${ }^{124}$ then a lack of party consent in predispute contractual terms renders the use of ADR inappropriate.

More contextually based challenges to mandatory ADR may also succeed, eventually. To the extent that particular uses of compulsory arbitration are fraudulent, corrupt, or overreaching, they may be voided in

118. See Reuben, supra note 8.

119. See Stephan landsman, THe ADVERSARy System: A Description and Defense (1984); STEPHAN LANDSMAN, AMERICAN BAR ASSOCIATION, READINGS ON ADVERSARIAL JUSTICE: THE AMERICAN APPROACH TO ADJUDICATION (1988).

120. See Jonathan R. Macey, Judicial Preferences, Public Choice and the Rules of Procedure, $23 \mathrm{~J}$. LEGAL STUD. 627 (1994).

121. 116 S. Ct. 1652 (1996).

122. 42 F.3d 1299 (9th Cir. 1994).

123. I do not mean by the statements in the text to associate myself with a rigid division between public and private, see Symposium, The Public/Private Distinction, 130 U. PA. L. REV. 1289 (1982), because I am of the view that these distinctions, like so many other in the law, often blur and are manipulated for legal, political, and policy reasons.

124. See Menkel-Meadow, supra note 5. 
particular contexts. ${ }^{125}$ Health care arbitrations may be treated differently than banking or securities claims, and even differences within employment arbitration procedures may be acknowledged by courts as having different contextual valences for evaluating the fairness of dispute procedures. For example, some commentators suggest that those who sign employment contracts in the securities industry ${ }^{126}$ may possess greater sophistication or understanding than others, ${ }^{127}$ therefore holding them to a different standard of consent to pre-dispute arbitration. ${ }^{128}$ Another approach, recently utilized by the D.C. Circuit Court of Appeals in Cole v. Bums International Security, ${ }^{129}$ guarantees certain due process protections in mandatory arbitration clauses, such as employer payment of legal representatives for employees and arbitrator compliance with statutory legal rights. If the preliminary findings of a recent empirical study of employment arbitration-finding that employment arbitrations managed by commercial, rather than employment rules of the AAA produce different outcomes ${ }^{130}$-turn out to be robust, it may be that courts will further scrutinize the operation of particular ADR processes in particular settings.

This discussion should illustrate the difficulties that emerge from the complexities and differences within each ADR process. As many of us have been urging for years, it makes little sense to talk about ADR as if it was a reified unitary form. ADR consists of a wide variety of

125. Such as in the claims before the California Supreme Court that Kaiser Permanente misrepresents how long it takes to get to arbitration (over 800 days compared to 300 days for trial in Oakland, see Engalla v. Permanente Med. Group, Inc., 43 Cal. Rptr. 2d 621 (1995)), and in at least one case failed to disclose that a particular arbitrator had a conflict of interest. The California legislature recently passed legislation to provide special protections for arbitrations in the health service industry. Health and Safety Code section 1373.20 provides specific procedures when arbitration is not administered by a "professional dispute resolution organization." See CAL. HeALTH \& SAFETY CODE $\$ 1373.20$ (a) (West Supp. 1997).

126. See Gilmer v. Interstate/Johnson Lane Corp., 500 U.S. 20 (1991).

127. Whether or not this is true is an empirical matter-just the kind of empirical assumption often asserted, but hardly ever fully examined, in the case law.

128. See, e.g., Great W. Mortgage Co. v. Peacock, 110 F.3d 222 (3d Cir. 1997); Pryner v. Tractor Supply Co:, 109 F.3d 354 (7th Cir. 1997); Ware, supra note 66.

129. 105 F.3d 1465 (D.C. Cir. 1997).

130. See Lisa B. Bingham, Emerging Due Process Concerns in Employment Arbitration: A Look at Actual Cases, 47 LAB. L.J. 108, 113 (1996) (finding differences in employment disputes arbitrated according to AAA commercial versus employment rules, but also finding that different kinds of disputes-executive grievances versus laborer discharge cases-were utilizing different rules and representational strategies, thus making disentangling of variables difficult and requiring further study). 
processes-each with increasing diversity in its variations ${ }^{131}$-that merits discussion, examination, and evaluation. If the dispute resolution professionals do not agree among themselves about the appropriate content of each process, outsiders cannot possibly understand the consequences of choosing an ADR process.

I do not mean to suggest that we can achieve some easy consensus among ourselves about what is meant by these terms; I doubt whether a profession as new, vibrant, creative, and competitive as ADR is ready to develop a clear protocol that all will adhere to, but I do think we should clarify these differences publicly to ensure that potential users of ADR know what they are getting. At this early stage of development, full disclosure may be all that we can achieve, leaving it to the concrete cases, market forces, and common law system to explore the full legal and economic ramifications of different kinds of processes. ${ }^{132}$ Although I will argue below that we need some ethical and regulatory controls on ADR services, I fear that any premature codification will rigidify and limit ADR's potential. ${ }^{133}$ In my view, any process that involves the parties in exploring their underlying interests, not just their legal claims, and broadens the possible scope of dispute resolution beyond the parties' crystallized dispute is an alternative to conventional legal processes. I am not sure that we have exhausted all of the possible forms such processes can take, or that we have fully theorized or even described what such processes can do.

\section{TO What USES SHOULd ADR BE PUT?}

As the lines between types of dispute processes blur, so do the possible uses to which ADR techniques can be applied. While mediation has long been used to resolve individual disputes, more modern adaptations and

131. Even simple dyadic negotiation has grown more complicated with suggestions for "tiered negotiations" to be used in commercial and international contracts employing ADR clauses. Negotiations may begin with the interested parties, but it is often easier to negotiate or settle cases when potentially responsible parties (with anger, guilt, or defensiveness) are removed from the institutional negotiations.

132. For an interesting argument that there are geographic and regional differences in the understandings of different processes and roles of third-party neutrals, see John Bickerman, Esq., Remarks at the D.C. Bar Association Administrative Law and Agency Practice Section, in ADR REPORT, June 25, 1997, at 11.

133. As one wise elder has said to me, "I know that mediation requires some formal rules, but I hope they are few. Too many and we will lose the essence." Letter from Jacob A. Stein, Esq., to Carrie Menkel-Meadow (April 29, 1997) (on file with author). 
applications of structured dispute resolution are being suggested for conflicts and controversies beyond the individual case. To the extent that traditional processes repetitively produce the same outcomes-such as compromises, command orders, and monetary "pay offs"-participants in a wide range of disputes now look for different ways to structure process in the hope of affecting both the process itself (for example, including more stakeholders), and the outcomes produced by these processes (such as power sharing, contingent agreements, in-kind transfers, and redesigned physical sites, to name just a few). This part will briefly review some of the areas in which new or differently structured processes might reconfigure how we deal with the various conflicts, goals, and needs of different groups. Like all other topics presented in this Article, there is no consensus that the use of alternative processes is an unmitigated improvement over the older, established processes; ${ }^{134}$ indeed, many strongly defend those processes that have served us well for so many years.

To the extent that our well-structured Constitution recognizes the advantages and limits of any one system of process, it has creatively provided for several processes-judicial, legislative, and executive processes of decision-making (separation of powers and checks and balances) and plural locations of the exercise of power (federalism). ${ }^{135}$ Despite the successes of these forms, each of them, in its own way, has come to depend in recent years on elaborations of different or alternative processes, borrowing from the core of techniques or ideology known as ADR. We have learned more and more about the advantages and defects of each process and of their ability to correct or supplement each other. Thus, as at the macro level of federal governmental processes, we are learning that there are particular logics or characteristics of particular ADR processes to be used in different situations.

Cognitive and social psychologists have recently discovered various distortions in human capacity to make decisions, to reason, ${ }^{136}$ and to bar-

134. The argument that particular processes or particular institutions have a particular logic or competence for dealing with particular disputes or outcomes is not new-this is simply a $1990 \mathrm{~s}$ version of the "institutional competence" argument of the Legal Process school of legal thought. See Henry M. Hart, Jr. \& Albert M. Sacks, The Legal Process: Basic Problems in the MAKING AND APPLICATION OF LAW (William N. Eskridge, Jr. \& Philip P. Frickey eds., 1994).

135. For a useful modern defense of Constitutional allocations of power, see ALAN BRINKELY ET AL., THE NEW FEDERALIST PAPERS (1997).

136. In a spirited oral debate I had with Amos Tversky at a conference at Stanford on conflict resolution theory in 1993, we argued about whether deviations from rational thinking needed explanation (on the theory that humans are rational), or whether conformity to rational thinking needed explanation (on the theory that decisions are more often based on emotive or affective and less rational bases). What constitutes reason or rational behavior is itself the subject 
gain with others over what we want. ${ }^{137}$ This research suggests that in order to overcome these psychological barriers, we will have to create different processes to correct these distortions. Lee Ross, for example, argues that humans devalue offers from the "other side" simply because they come from the other side. ${ }^{138}$ This process of "reactive devaluation" is often corrected by having an intermediary suggest solutions, detached from the interests of either side, thus prompting a neutral consideration of the merits of the proposal. Thus, we have one justification for the use of mediators in highly contested settings. Similarly, because strategic thinking impairs our ability to reveal information we fear the other side will exploit, the mediator may gather more information than parties would share if left to their own devices. Thus, mediators may be superior information gatherers and processors to a judge or the parties themselves. ${ }^{139}$ In game-theoretic terms, Howard Raiffa describes the mediator's function as ensuring that no waste is left on the table; that is, the parties use the optimal amount of information to craft a Pareto optimal solution. ${ }^{140}$ While these applications of behavioral research are being made in the negotiation and private disputing context, they also have applicability to public policy driven conflicts as well, as I will briefly explore below. Departures from legally created institutional arrangements or designated process, however, also raise difficult issues of legitimacy and authorization within our legal structure. ${ }^{141}$ To what extent, for example, can a community-convened

of much academic debate at the present time. See DONALD P. GREEN \& IAN SHAPIRO, PATHOlOgies OF RATIONAL ChOICE THEORY (1994); JAMES Q. WILSON, Beyond SelfINTEREST (Jane J. Mansbridge ed., 1990) [hereinafter WILSON, BEYOND SELF-INTEREST]; JAMES Q. WILSON, THE MORAL SENSE (1993). I am happy to report that the "mixed motive" theorists seem to be winning the day. There is a rich and fertile field of possible application of this important theoretical work on human motivation and behavior for conflict resolution behavior and theory, and it is just beginning to be fully explored.

137. See BARRIERS TO CONFLICT RESOLUTION (Kenneth J. Arrow et al. eds., 1995); Gary Goodpaster, Rational Decision-Making in Problem-Solving Negotiation: Compromise, Interest-Valuation, and Cognitive Error, 8 OHIO ST. J. ON DISP. RESOL. 299 (1993); Robert H. Mnookin, Why Negotiations Fail: An Exploration of Barriers to the Resolution of Conflict, 8 OHIO ST. J. ON DiSP. RESOL. 235 (1993).

138. See Lee Ross, Reactive Devaluation in Negotiation and Conflict Resolution, in BARRIERS TO CONFLICT RESOLUTION, supra note 137 , at 26.

139. See Brown \& Ayres, supra note 114; cf. Ayres \& Nalebuff, supra note 114.

140. See Howard Raiffa, Post Settlement Settlements, in NEgOTIATION THEORY AND PRACTICE 0. William Breslin \& Jeffrey Z. Rubin eds., 1991).

141. For an interesting argument that modern dispute resolution processes are consistent with separation of powers and federalism and would likely have been approved of as acceptable American processes by Alexis de Tocqueville, see Stephanie M. Herseth, How Alternative Dispute Resolution Processes Affect Fundamental Tensions Within the Democratic Soul (1997) (paper submitted in ADR policy course, Georgetown Law Center) (on file with author). At the 
mediation process over a land-use problem substitute for or supplement the legislatively created zoning process? ${ }^{142}$

In the judicial or litigation context, I have labeled the defenders of the old model the "litigation romanticists." These are individuals who still believe that the adversary system-with its neutral judge and two adversarial contestants publicly conducting disputes about the facts ${ }^{143}$ or the law to be applied-best resolves disputes and produces rules for the rest of society. Litigation clearly has its place, and I have never advocated that it should be completely eliminated. Nevertheless, the adversarial structure of argument and case presentation, as well as rules of procedure and evidence, sometimes severely constrain the definition of problems, the participants, and the legally permitted outcomes. In its most common form of usage, $\mathrm{ADR}$, or mediation or arbitration of individual disputes, allows parties to select decisionmakers, choose rules of procedure, and decide on the desired outcomes, ${ }^{144}$ thus returning control of the process to the parties. Such processes also allow parties to arrive at solutions that are often not possible in traditional legalistic outcomes, such as future-oriented agreements or sharing arrangements.

Whatever the merits of the use of ADR in individual disputes (and there are those who strongly believe that even private disputes are "public matters"145), the use of some ADR-like settlement devices in several recent class actions provoked a sharp debate about the tensions between individual and aggregate justice. ${ }^{146}$ The uses of ADR in class actions

same time, we do have to worry that public dispute resolution fora used to deal with siting or environmental problems, for example, do not fully usurp other democratic or regulatory processes.

142. See SUSSKIND \& CRUIKSHANK, supta note 17.

143. See Laura Macklin, Promoting Settlement, Foregoing the Facts, 14 N.Y.U. REV. L. \& Soc. CHANGE 575 (1986).

144. Such "derived outcomes" consist of a decision through arbitration, a facilitated settlement through mediation, or private settlement through negotiation.

145. See, e.g., Fiss, supra note 9; David Luban, Essay, Settlements and the Erosion of the Public Realm, 83 GEO. L.J. 2619 (1995); Menkel-Meadow, supra note 5, at 2667 n.24.

146. For some entries in this debate, see, for example, Koniak \& Cohen, supra note 59. See also RICHARD B. SOBOL, BENDING THE LAW: THE STORY OF THE DALKON SHIELD BANKRUPTCY (1991) (describing Dalkon Shield litigation and bankruptcy); John C. Coffee, Jr., Class Wars: The Dilemma of the Mass Tort Class Action, 95 ColUM. L. REV. 1343 (1995); Deborah R. Hensler, A Glass Half Full, A Glass Half Empty: The Use of Altemative Dispute Resolution in Mass Personal Injury Litigation, 73 TEX. L. REV. 1587 (1995); Susan P. Koniak, Feasting While the Widow Weeps: Georgine v. Amchem Products, Inc., 80 CORNELL L. REv. 1045 (1995); Carrie Menkel-Meadow, Ethics and the Settlements of Mass Torts: When the Rules Meet the Road, 80 CORNELL L. REV. 1159 (1995); Judith Resnik et al., Individuals Within the Aggregate: Relationships, Representations and Fees, 71 N.Y.U. L. ReV. 296 (1996); Brian Wolfman \& Alan Morrison, Representing the Unrepresented in Class Actions Seeking Monetary Relief, 71 N.Y.U. L. Rev. 439 (1996); see also Eric D. Green, What Will We Do When Adjudication Ends? We'll Settle in Bunches: Bringing Rule 23 into the 
have been varied, ${ }^{147}$ including: a choice of ADR in the form of arbitration in Dalkon Shield; appeals for mediation or arbitration after "grid" assessments of compensation in asbestos ${ }^{148}$ and breast implant ${ }^{149}$ cases; and now similar uses of mediation or other forms of ADR following grid-like claims assessments in the class action settlements of major insurance fraud cases. ${ }^{150}$ In contrast to consumer or securities class actions settlements in which claimants receive either nominal amounts of money or simple discounts on future purchases of goods, ${ }^{151}$ some of the recent uses of $A D R$ in the mass tort or insurance context permit a hearing to contest or present evidence on amounts to be received. Without recounting all of the complex arguments concerning the elasticity of Rule 23, ${ }^{152}$ in my view, applications of ADR processes to class actions offer the promise of process integrity and catharsis for individual disputants ${ }^{153}$ while preserving some of the efficiencies and benefits of mass litigation. To the

Twenty-First Century, 44 UCLA L. REV. 1773 (1997); Francis E. McGovern, Rethinking Coopetation Among Judges in Mass Tort Litigation, 44 UCLA L. REV. 1851 (1997). For representative cases, see Georgine v. Amchem Products, Inc., 83 F.3d 610 (3d Cir. 1996), cert. granted sub nom. Amchem Prods., Inc. v. Windsor, 117 S. Ct. 379 (1996); see also Amchem Products Inc. v. Windsor, 117 S. Ct. 2231 (1997) (rejecting class treatment for settlement of national class in asbestos litigation); In re Asbestos Litig., 90 F.3d 963 (5th Cir. 1996), affg Ahearn v. Fibreboard Corp., 162 F.R.D. 505 (E.D. Tex. 1995); In re Silicone Gel Breast Implant Prods. Liab. Litig., No. CV 92-P-10000-5, 1994 WL 578353 (N.D. Ala., Sept. 1, 1994).

147. For $m y$ extended views on the abbreviated discussion here, see Menkel-Meadow, supra note 146. I have been a participant in several of the recent mass tort cases: I served as a mediator in the Wellington Asbestos Facility (and its successor CCR), an arbitrator in Dalkon Shield claims settlement, and an advisor to the settlement counseling process in the breast implant litigation. I have also served as a mediator and advisor in several less notorious mass tort or products liability cases.

148. See In re Joint E. and S. Dists. Asbestos Litig., 929 F. Supp. 1 (E.D.N.Y. \& S.D.N.Y. 1996); see also JACX WENSTEN, INDIVIDUAL JUSTICE IN MASS TORT LMTIGATION (1995).

149. See supra note 146.

150. See New York Life Insurance Case, ADR is Key to Class Action Settlement, 14 ALTERNATIVES 1 (1996) (describing arbitration of claims after rejection of claims assessment in major life insurance fraud class action settlement); Leslie Scism, Prudential Restitution Could Top \$1.6 Billion, WALL ST. J., May 30, 1997, at A-3; Settlement Approved in Prudential Case, N.Y. TIMES, Mar. 11, 1997, at D-4.

151. See In re General Motors Corp. Pick-Up Truck Fuel Tank Prods. Liab. Litig., 55 F.3d 768 (3d Cir. 1995); In re Domestic Air Transp. Antitrust Litig., 148 F.R.D. 297 (N.D. Ga. 1993). Although discount coupon settlements are now much criticized, I remember receiving a book discount coupon for a class action settlement of price fixing in a bar review course many years ago, and thinking at the time that it was pretty close to a win-win solution-I love books, and Harcourt, Brace and Jovanavich got to keep most of its money and get rid of remaindered books. Some evidence suggests that companies that do pay out in class actions or respond to consumer complaints are more likely to get repeat business.

152. See Amchem Prods., Inc. v. Windsor, 117 S. Ct. 2231 (1997) (holding that the Rule 23 requirements of typicality and representativeness were not met in attempted global settlement and national class action in asbestos litigation).

153. See WEINSTEN, supra note 148. 
extent that federal judges cannot hear all the claims in a class action, it may still be important for claimants to have a hearing, "vent" their anger, concerns, emotions, and harms experienced, and to tell their story, ${ }^{154}$ as well as to explore a more individualized assessment of their claims. Various forms of ADR, when incorporated into class action settlements, provide the potential (even if the potential is not yet realized in the current cases).

What is required, in my view, is a more sophisticated understanding of the different processes and forms of ADR, and the situations in which they are best applied. In cases involving strictly monetary value, arbitration following some claim assessment may be appropriate because of its "decisional" quality; but in cases in which the parties want to participate in more open-ended narrative about what happened to them or seek some negotiation over some nonmonetary claims (such as in some of the mass tort cases), then mediation or other ADR forms may be more appropriate (when more variable and flexible solutions are possible). It is important that particular forms of ADR not become inflexibly and rigidly adopted in repetitive form in these cases. To borrow Maurice Rosenberg's artful phrase, we may need to adapt the "forum to the fuss"155 and consider what kinds of ADR processes are appropriate in different kinds of mass cases to maximize the individualized treatment that is most appropriate for each particular claim. In my own experience, some claimants desire an inperson "confrontation" with some representative of the wrongdoer, whereas others are quite content to accept a more anonymous payment. Different litigants may desire different processes and/or remedies, ${ }^{156}$ and offering an adaptive menu of process choices could respond to these different requirements within mass litigation settings.

154. For a discussion of the now well-documented need for parties to experience "procedural justice" as a part of their assessment of the legitimacy of any process, see THOMAS TYLER \& E. Allan lind, The Social Psychology of Procedural Justice (1988).

155. See Frank E.A. Sander $\&$ Stephen B. Goldberg, Fitting the Forum to the Fuss: Factors to Consider When Selecting an ADR Procedure, 12 ALTERNATIVES 48 (1994); Frank E.A. Sander \& Stephen B. Goldberg, Fitting the Forum to the Fuss: A User-Friendly Guide to Selecting an ADR Procedure, 10 NEgOTIATION J. 49 (1994).

156. See John M. CONLEY \& William M. O'BARR, Rules and Relationships: The ETHNOGRAPHY OF Legal DISCOURSE (1990); SAlly ENGLE MERRY, GETTING JUSTICE AND GETTING EVEN: LEGAL CONSCIOUSNESS AMONG WORKING-ClasS AMERICANS (1990); Sally Engle Merry \& Susan S. Silbey, What Do Plaintiffs Want? Reexamining the Concept of Dispute, 9 JUST. SYS. J. 151 (1984). 
Outside of conventional litigation, ADR processes have appeared in a variety of governmental settings, including administrative rule making and other executive agency settings. ${ }^{157}$ While some doubt that the adversarial relations between the regulated and the regulators will ever change the legal culture (particularly in the enforcement branches of the government), even the U.S. Justice Department initiated a full-scale program to train its lawyers (and clients) through federal agencies and the U.S. Attorney's Offices to employ ADR and explore other approaches to civil litigation and some forms of law enforcement. ${ }^{158}$ In one sense, governmental and administrative recognition of $A D R$ processes comes late to the use of $A D R$ in public policy disputes. Skilled mediators have been using negotiation, mediation, and other conflict resolution processes for years in the areas of the environment, the budget, land-use, and other allocative problems. ${ }^{159}$ The use of conflict resolution techniques recognizes that adversarial opposition of only two parties (plaintiff/defendant, or government/regulated, or build it/NIMBY forces) is not likely to result in the best possible solution available. Rather than this binary model, ADR fosters participation by multiple stakeholders with expert facilitators who structure discussion ${ }^{160}$ and guide brainstorming, and ADR has proven more successful in some environments than the more cumbersome and oppositional presentation of draft rules, publication, adversarial hearings, and contested enforcement actions. These collaborative processes have proven useful not only in generating more acceptable and broadly gauged solutions, but because more open and participatory conversations and dialogues can redefine the problems, explore underlying interests and conflicts, and deal more comp-

157. See Charles Pou, Jr., Reauthorized Laws Show Govemment's ADR Comfort Level is Increasing, 15 ALTERNATIVES 15 (1997) (reporting on the Administrative Dispute Resolution Act of 1996 authorizing the use of ADR in federal agencies and providing for confidentiality protections for neutrals, exceptions to Freedom of Information Act requests, and increased use of arbitration by federal agencies); Lawrence E. Susskind et al., When ADR Becomes the Law: $A$ Review of Federal Practice, 9 NeGOTIATION J. 59 (1993).

158. See Exec. Order No. 12,988, 3 C.F.R. 157 (1996); see also D.C. Bar Members Discuss New Developments in ADR, ADR REP., June 25, 1997, at 11 (remarks of Peter Steenland, Esq., ADR Special Counsel in the Office of the Associate Attorney General).

159. See SUSSKIND \& CRUIKSHANK, supra note 17; SUSSKIND \& FIELD, supra note 17; Patricia M. Wald, Negotiation of Environmental Disputes: A New Role for the Courts?, 10 COLUM. J. ENVTL. L. 1 (1985).

160. For one example of the literature describing these functions, see ROGER M. SCHWARTZ, THE SKILlED FACILITATOR (1994). 
rehensively with underlying issues. ${ }^{161}$ Reg-neg, which involves on-going dialogue between the regulators and the regulated in the drafting stages of regulation in the hopes of averting post hoc challenges to rules, has been utilized in a variety of regulatory settings, including environmental, food and drug, labor and safety standards, banking and consumer, and trade regulation. While there are not yet definitive empirical studies, ${ }^{162}$ case study reports suggest that when well designed and managed, these large groups of stakeholders and interest groups can work together to substantively draft rules, develop plans, or agree on enforcement terms.

In the private sector, ADR application has been most successful in the construction field, in which the concept of "partnering" brings the parties to a construction project together before it begins in order to develop good relations and to establish procedures for dispute resolution. ${ }^{163}$ To the extent that some industries recognize the long-term relational aspects of their business, they will likely seek both an efficient and lasting resolution of their problems. ${ }^{164}$ The dilemma in fostering creative on-going dispute

161. See Freeman, supra note 38 (discussing when such processes work and also what are, as currently structured, their limitations). Freeman reports that although problem-solving orientations have much to offer administrative processes (in terms of promising more participatory processes and more flexible solutions), the current structures of such processes perpetuate "oneshot" deal making and simple "split the difference" bargains, rather than exploring more continuous, contingent, and provisional solutions with on-going monitoring and relationship building.

162. See Part VI of this Article for a fuller discussion of the evaluation problems in the ADR field generally. In the area of reg-neg, we do have some in-depth case study reports that show mixed success but a high learning curve from what has been accomplished thus far. See Freeman, supra note 38 .

163. In their fullest forms, these "partnering" programs include psychological testing and evaluation of the parties, group process and consensus-building activities, and a range of technical sessions and meetings. See James P. Groton \& William R. Wildman, The Role of Job-Site Dispute Resolution in Improving the Chances for Success on a Construction Project, CONSTRUCTION LAW., Aug. 1992, at 1; Thomas J. Stipanowich, Beyond Arbitration: Innovation and Evolution in the United States Construction Industry, 31 WAKE FOREST L. REV. 65, 127-28 (1996). I have often found it wonderfully ironic and interesting that the Army Corps of Engineers, large construction companies, and other "tough" professionals have been among the most innovative and creative in adapting to dispute resolution and behavioral changes, often including the most new-age sorts of exercises in their programs for building dams, tunnels, roads, bridges, and major construction projects. A recent survey of the construction industry found, for example, that "while the concept [of partnering] is still beyond the experience of many attorneys, partnering has relatively high visibility among other professional groups and has been most heavily employed in the public sector." Stipanowich, supra, at 144.

164. Professor Thomas Stipanowich points out that the construction industry has been particularly well positioned to illustrate the informal law making and dispute resolution that occurs in "relational" contexts. It is also interesting and ironic to note here that "relational" feminist theory (with which I am associated, see Carrie Menkel-Meadow, What's Gender Got to Do With It? The Politics and Morality of An Ethic of Care, 22 N.Y.U. REV. OF L. \& SOC. CHANGE 265 (1996)), may suggest models for legal relations and dispute resolution in areas not commonly considered to 
resolution processes in such relational contexts is to provide fair and participatory processes without allowing one interest group to co-opt or capture the process, because they must deal with each other over time. ${ }^{165}$

Similar facilitated group meetings have been used in public policy disputes, such as environmental, local land use, zoning disputes, and labor disputes. As these "mini-democracies" develop in community- and interestbased groups, some argue that dispute resolution processes themselves can serve to empower communities, as well as individuals. Lawrence Susskind has eloquently argued that dispute resolution processes can enhance community participation by facilitating democratic participation in a wide range of issues. ${ }^{166}$ In Susskind's model, participants to a group decisionmaking process are trained in negotiation before the process begins, thereby empowering them to deal with each other on an equal skill level, if not at an economic level. In addition, foundation funding or economic pooling balances some of the power disparities that often occur in environmental or development contexts.

On the other hand, to the extent that large developers, like Wal-Mart, have become repeat players in local community development issues, it is important to consider whether the advantages of the repeat player in litigation $^{167}$ may be replicated in the more informal settings of community negotiations or fora. ${ }^{168}$ Those who facilitate public policy dispute fora or consensus-building negotiations must remember that these procedures oper-

be within feminists' purview. Cf. Carrie Menkel-Meadow, Mainstreaming Feminist Legal Theory, 23 PAC. L.J. 1493 (1992).

165. See John Shepard Wiley, Jr., A Capture Theory of Anti-Trust Federalism, 99 HARV. L. REV. 713 (1986).

166. See John Forester, in WHEN TALK WORKS, supra note 91 (providing a profile of Lawrence Susskind).

167. See Marc Galanter, Why the "Haves" Come out Ahead: Speculations on the Limits of Legal Change, 9 L. \& SOC'Y REV. 95 (1974).

168. In attempting to find a term capacious enough to include mediation, consensus-building fora, reg-neg, public policy dispute fora, and the other descriptors of multi-party dispute resolution settings, it became clear to me that we do not have a single term that best describes these varieties of processes. Larry Susskind and Jeffrey Cruikshank call them "negotiated approaches to consensus building." BREAKING THE IMPASSE, supra note 17, at 11. The construction industry calls them "partnering," and I (and others) have called them "intermediate sites" of democratic participation. See Menkel-Meadow, supra note 14; Menkel-Meadow, supra note 91. Jody Freeman uses the term "collaborative processes" in the administrative state; others call them "facilitated processes" or "dispute systems." See CONSTANTINO \& MERCHANT, supra note 37, at

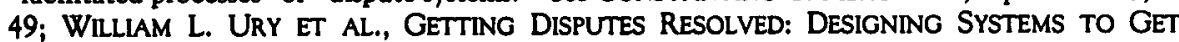
DISPUTES RESOLVED (1988). Still others refer simply to dialogues or conversations, see Lani Guinier \& Susan Sturm, Reflections on Race Talk (manuscript on file with author), or to coalitional bargaining or consensus, see Gary Goodpaster, Coalitions and Representative Bargaining, 9 OHIO ST. J. ON DISP. RESOL. 243 (1994). 
ate as supplements-not substitutes-for legally constituted requirements (such as zoning regulations) or elected bodies (such as Planning Commissions, School Boards, and so on). Thus, a growing area of interest for practice and research is how negotiated processes conducted outside of conventional legal fora can be incorporated into, or utilized in connection with, the formal requirements for law making and decision making in those contexts in which public issues and interests are at stake. ${ }^{169}$

Recently, several political leaders have suggested expanded uses of ADR-like fora to resolve hotly contested issues that have been stalemated by conventional political processes. For example, former Governor Mario Cuomo suggested that we utilize some form of ADR process to deal with campaign finance reform and social security reform, issues traditionally deadlocked because of partisan party politics. ${ }^{170}$ In such settings, Congress or the Executive Branch could use neutrals or experts to find facts, make recommendations across interests and partisan lines, and hold dialogues or interactive conversations, rather than engaging in the traditional adversarial question-and-answer formats. ${ }^{171}$

The application of ADR and negotiation techniques to governmental settings presents unique challenges, however. One of my former students who worked on Capitol Hill as a legislative aide reported that the principled and interest-based negotiation methods he had learned in my negotiation course were of little use to him in a climate in which bargains were more often unprincipled log-rolling trades of regional or geographic selfinterest. ${ }^{172}$ It may, perhaps, be somewhat ironic that consensus-building

169. As a mediator for the United States Court of Appeals for the District of Columbia Circuit Court this is a very real theoretical and practical problem. To what extent can federal agencies seek mediated solutions to problems (often including non-litigants in mediation processes) to seek good and stable solutions to problems when laws, regulations and federal policies seriously constrain the decision-making environment. Such cases implicate important issues of accountability as well. For a more comprehensive review, see text accompanying notes 226-231.

170. Governor Mario Cuomo, Lunch Address at the Center for Public Resources, New York City-The Uses of ADR in Public Life Winter Meeting (January 31, 1997).

171. On the other hand, some public officials argue against "bi-partisanship" fearing that principles will be compromised and "split the difference" brokered settlements will exclude important interests and parties. See, e.g., Robert B. Reich, Up from Bi-Partisanship, AM. PROSPECT, May-June 1997, at 26 (arguing that political compromise toward the "feeble center" on important political issues disenfranchises the economically vulnerable and compromises important democratic values and principles). In addition, political figures who are responsive to party interests may feel that some conflicts are not resolvable. House Minority Leader Richard Gephardt recently said of his role in Congress (following the Hershey "Civility Retreat" for Congress officials), "Our job is to resolve conflict, knowing that the conflict will never be truly resolved." ROLL CALL, Mar. 6, 1997, at 3 (recognizing that although legislatures may "resolve" conflicts by passing legislation, there are many value conflicts that may never truly be resolved).

172. This source must remain anonymous for obvious reasons. 
fora or policy negotiations must be conducted in parallel or in shadow to the more public "main show" in order to accomplish results. ${ }^{173}$ Consensus building is also difficult, though not impossible, in highly hierarchical environments because appropriate decisionmakers and stakeholders must be identified for the efficacy of any agreement reached. ${ }^{174}$ Thus, use of principled negotiation and conflict resolution techniques may offer some promise in the political arena, as long as the challenges of "valuedriven" 175 conflicts in high visibility and hierarchical environments are considered.

Among ADR's most controversial uses involves the use of mediation in criminal settings, ${ }^{176}$ in which victim-offender mediation offers the possibility of more flexible and adaptive punishments through restitutionary and compensatory schemes, as well as offering a channel for remorse, acknowledgment, and reconciliation. ${ }^{177}$ Indeed, grievance arbitrations were commonly used in prisons twenty years ago ${ }^{178}$ and are increasingly mentioned as a possibility for dealing both with internal prison conflict and

173. Shadow negotiations are, of course, often used in the international arena, often quite successfully. See Herbert C. Kelman, Contributions of an Unofficial Conflict Resolution Effort to the Israeli-Palestinian Breakthrough, 11 NEGOTIATION J. 19 (1995). Some negotiations and ADR techniques work best when they promise privacy to the parties and proposals can be tested in a confidential, non-public and therefore less risky environment. The privacy of some ADR techniques run counter to some of the ideology of democratic participation of consensus-building community formats, but are an often necessary party of mediation and conflict resolution techniques. On the different approaches to mediation "caucus" techniques, see GARY J. FRIEDMAN, A Guide to Divorce Mediation: How to Reach a FalR, legal SETtlement at a FrACTION OF THE COST 279-93 (1993); CHRISTOPHER MOORE, THE MEDIATION PROCESS 319-26 (2d ed. 1996); Menkel-Meadow, supra note 91.

174. For many years, lawyers ordered to mediation with government lawyers complained that the government officials with appropriate "settlement authority" were never present, and thus mediations with the government were a sham. In the private sector, plaintiff lawyers have similar complaints about insurance representatives.

175. For an excellent discussion of how value conflicts present particularly intractable, but sometimes still "workable" conflicts, see SCHON \& REIN, supra note 58; SUSSKIND \& FIELD, supra note 17, at 177-97 (describing conflict resolution with animal rights groups).

176. See Jennifer Gerarda Brown, The Use of Mediation to Resolve Criminal Cases: A Procedural Critique, 43 EMORY L.J. 1247 (1994).

177. See Robert B. Coates \& John Gehm, Victim Meets Offender: An Evaluation of Victim-Offender ReCONCILIATION Programs (1985); MARK S. UMBReIT ET AL., Victim MEETS OFFENDER: THE IMPACT OF RESTORATIVE JUSTICE AND MEDIATION (1994).

178. See Howard Lesnick, Grievance Procedures in Federal Prisons: Practices and Proposals, 123 U. PA. L. REV. 1 (1974). Twenty years later, the prison remains a site for consideration of alternatives to traditional litigation, even in the use of reform-oriented impact litigation. See Susan P. Sturm, Resolving the Remedial Dilemma: Strategies of Judicial Intervention in Prisons, 138 U. PA. L. ReV. 805 (1990); see also Susan P. Sturm, The Legacy and Future of Corrections Litigation, 142 U. PA. L. Rev. 639 (1993); Susan P. Sturm, A Normative Theory of Public Law Remedies, 79 GeO. L.J. 1355 (1991). 
the demands of prisoner civil rights litigation. To the extent that some social science research suggests that different and more responsive bargains can be struck with particular criminal defendants, ${ }^{179}$ this criminal "bargaining" may also meet the needs of society and defendants by reducing crime and court dockets, ${ }^{180}$ as well as providing more particularized treatment and punishment for offenders. ${ }^{181}$

At earlier stages of the criminal process, mediation has become one of the leading tools in preventing violence through the extensive use of peer mediation programs in schools at all levels. ${ }^{182}$ In addition to promoting nonphysical conflict resolution, school mediation programs typically instruct students in problem-solving skills, listening, and communication exercises and may, when most successful, counteract some of the more adversarial and competitive aspects of student culture. To the extent that young citizens learn to "use their words," instead of their fists, we may combine the rigors of reading, writing, and "rithmetic with the new "4th $\mathrm{R}$," resolution.

At higher levels of education, universities use ADR-like fora to discuss highly conflictual issues. Dialogues, forums, and "teach-ins" model how to possibly discuss such divisive issues as race relations, diversity and affirmative action, abortion, sexual harassment, hate speech, and fraternity life in structured nondebate settings. At UCLA, my colleague Howard Gadlin and I sponsored ${ }^{183}$ a nondebate forum on affirmative action (including the use of questions designed to explore areas of agreement as well as disagreement-areas in which more information was necessary and including the restatement of other parties' positions). ${ }^{184}$ Howard Gadlin's class on conflict resolution engages students in creating dialogues and forums to develop other structures for such conversations. Lani Guinier and Susan Sturm have similarly structured their course on race and gender theory

179. See Pamela J. Utz, Settring the Facts: Discretion and Negotiation IN Criminal Court (1978).

180. Determinate sentencing guidelines, of course, make discretionary and individually sensitive negotiations impossible, but even the federal government has begun consideration of how $A D R$ might possibly be used in some criminal matters (especially when, as in environmental cases, criminal penalties are often accompanied by various civil enforcement and damage actions).

181. See SOL WACHTLER, AFTER THE MADNESS (1997).

182. The attorney general has taken a particular interest in peer mediation for children, spending her own personal time on attendance at school mediation programs in the District of Columbia and elsewhere in the country. See Attorney General Janet Reno, Plenary Speech at the SPIDR National Conference, Anaheim, Calif. (Sept. 1996); TIME, Nov. 25, 1996, at 42.

183. As co-directors of the UCLA Center for Inter-Racial, Inter-Ethnic Conflict Resolution.

184. This forum is more fully described in Menkel-Meadow, supra note 14, at 34-35. 
along similar lines, ${ }^{185}$ providing educational strategies and environments that alter the "either-or," top down, or debate form of classroom dialogue. To the extent that educational environments provide laboratories for alternative ways to construct learning environments, universities can experiment with alternative forms of conversation and decision making. ${ }^{186}$

Finally, as citizens of an increasingly multi-cultural world, we are learning to process conflict and resolve disputes in a variety of different ways, both within our own diverse nation and in the international fora in which we participate. Several recent international trade treaties and organizations provide for various forms of ADR as one way to avoid the legal domination of any one particular legal culture. ${ }^{187}$ Through participation in the global economy and mass media exposure concerning other ways of doing business or resolving problems, our citizens are learning that winning a lawsuit may not be the only way to resolve conflicts. There are, of course, conflicts about whether harmony justice pacifies the population, ${ }^{188}$ or whether some forms of ADR, like mediation, can be used to serve political purposes. ${ }^{189}$ In addition, the international commercial arbitration arena is characterized by nationalistic competitions over both choice of law and choice of arbitrators, ${ }^{190}$ and it remains to be seen whether ADR will become the "lingua franca" of international disputes or whether it will be culturally or politically captured by particularly powerful nations or individuals.

Even in the domestic arena of multi-cultural disputing, some suggest that ADR privileges certain ethnocentric or culturally specific values and

185. See Guinier \& Sturm, supra note 167. They include such techniques as selecting for critical masses of "represented groups" so that no individual is a token representative of their demographic position, using student-led and directed conversations, and providing for clear feedback rules.

186. Even the American Association of Law Schools has recognized the importance of facilitated and structured consensus-building environments. It has recently established a Resource Corps of professional trained facilitators designed to help law schools manage internal conflict and hold structured planning meetings and it has scheduled a workshop for deans to learn conflict and change management techniques. See 1997-98 Professional Development Programs Announced, NEWSLETTER (Ass'n Am. Law Schools), Feb. 1997, at 12-13.

187. See, e.g., Pierre Pescatore et al., HandBook OF WTO/GatT Dispute Settlement (1991); NoRTH American Free Trade Agreements: Dispute SetTlement (James R. Holbein \& Donald J. Musch eds., Oceana Pub. 1997); THE WORLD TRADE Organization, The WTO Dispute Settlement Procedures: A Collection of the Legal TExTs (1995),

188. See Nader, supra note 30.

189. See, e.g., Stanley Lubman, Mao and Mediation: Politics and Dispute Resolution in Communist China, 55 CAL. L. REV. 1284 (1967).

190. See Dezalay \& GarTH, supra note 31 , at 7 . 
attributes. To the extent that one is required to talk through a problem and speak directly to other parties in a dispute, some forms of mediative "talking cures" may privilege American cultural forms of talk, ${ }^{191}$ selfrevelation, and blame, rather than other cultural emphases on community, harmony, humility, and privacy. ${ }^{192}$ Some worry that certain forms of ADR disserve racial minorities or other disadvantaged groups and individuals when dispute resolution assumes equality of disputants or privatizes proceedings and "hides" claims. ${ }^{193}$

There are many complex and challenging issues to be faced when alternative forms of dispute processing are applied to cultures with set patterns and procedures. It remains to be seen whether administrative agencies, legislatures, schools, families, or local communities can change their usual patterns of dealing with conflicts or resolving disputes any more easily than can courts. The potential for different modes of problem solving is there, and a growing tool-kit of strategies, coupled with research efforts to evaluate innovations and develop theories of conflict resolution, in different contexts, offer us the opportunity to test these new processes to examine their strengths and weaknesses. At the level of justice and theory, they offer us the potential of greater party participation and more responsive solutions to individual and social problems, but they also threaten accepted forms of governmental and legal authority and legitimacy. As a result, some urge tight regulation of these practices.

191. For an argument that styles of articulation are gender based, as well as situationally and culturally structured, see DEBORAH TANNEN, TALKING FROM 9 TO 5 (1994); DEBORAH TANNEN, YOU JUST DON'T UNDERSTAND: WOMEN AND MEN IN CONVERSATION (1990).

192. For at least one attempt to develop some sensitivity to disputing across cultures, within our own diverse nation, see SELMA MYERS \& BARBARA FILNER, MEDIATION ACROSS CULTURES: A HANDBOOK ABOUT CONFLICT AND CULTURE (1993).

193. See, e.g., Michele Herman et Al., METro Court Project Final RePORT (1993) (studying the effects of ethnicity and gender in mediated and adjudicated small claims cases at the Metropolitan Court Mediation Center at Albuquerque, New Mexico); Richard Delgado et al., Fairness and Formality: Minimizing the Risk of Prejudice in Altemative Dispute Resolution, 1985 WIS. L. REV. 1359; Isabelle R. Gunning, Diversity Issues in Mediation: Controlling Negative Cultural Myths, 1995 J. DISP. ReSOL. 55; Gary LaFree \& Christine Rack, The Effects of Participants' Ethnicity and Gender on Monetary Outcomes in Mediated and Adjudicated Civil Cases, 30 L. \& Soc'Y REV. 767 (1996). But see Wallace Warfield, Building Consensus for Racial Harmony in American Cities: A Case Model Approach, 1996 J. DiSP. RESOL. 151 (suggesting that mediation and consensus-building techniques, called Collaborative Problem Solving Processes, can be used to help achieve racial social justice and recognizing that "neutrality" is unlikely to exist in third-party intervenors in deep-rooted racial conflicts). 


\section{ETHICS AND STANDARDS IN THE USE OF ADR: HOW SHOULD ADR BE REGULATED?}

Whether there is a unifying theory or logic to ADR practices is, of course, one of the themes of this Article. As ADR practices and processes proliferate into a wide range of different techniques, processes, and providers, some argue for the regulation of such practices. I have previously written at great length about the variety of issues implicated in the "ethics of ADR,"194 so I will only sketch those issues here. At the outset, it is important to recognize that like any fledgling profession, $\mathrm{ADR}$ practitioners seek to regulate themselves through a wide variety of internal and professional association standards and protocols. However, given the multidisciplinary base of professionals practicing dispute resolution, proposed "transdisciplinary" ethics codes or standards have been vague and general. Several states including Florida, Texas, and Minnesota have promulgated statutory standards, and in some cases, formal regulatory and disciplinary enforcement mechanisms. Thus, one of the interesting tensions in the field is the extent to which ethical standards and regulation will remain internally driven, as external regulatory bodies develop more regulations and rules and courts rule on the ethical and practice questions that are litigated. ${ }^{195}$ In addition, there are interesting questions concerning the scope of ethical or regulatory standards in ADR. Some of these ethical issues sufficiently mirror and parallel those discussed in regulating lawyers (such as fee structures, malpractice, and confidentiality). Others are different and may require more specific ethical guidelines-for example, distinguishing conflicts of interests for neutrals from representatives, different practices in mediation and arbitration, obligations of provider organ-

194. See Carrie Menkel-Meadow, Ancillary Practice and Conflicts of Interests: When Lawyer Ethics Rules Are Not Enough, 13 ALTERNATIVES 15 (1995); Carrie Menkel-Meadow, Conflicts of Interest in Mediation Practice, DISP. RESOL. MAG., Spring 1996, at 5; Carrie Menkel-Meadow, Ethics in Alternative Dispute Resolution: New Issues, No Answers from the Adversary Conception of Lawyers' Responsibilities, 38 S. TEX. L. REV. 405 (1997); Carrie Menkel-Meadow, Ex Parte Talks with Neutrals: ADR Hazards, 12 ALTERNATIVES 109 (1994); Menkel-Meadow, supra note 51; Menkel-Meadow, supra note 23; Carrie Menkel-Meadow, Public Access to Private Settlements: Conflicting Legal Policies, 11 ALTERNATIVES 85 (1993); Menkel-Meadow, supra note 57.

195. This tension is not unique to ADR. The legal profession continues to feel this tension in its efforts at self-regulation, while more and more pressure is placed by consumer groups and various governmental bodies to regulate the profession from outside. 
izations, obligations of neutrals to maintain neutrality while employing "power balancing" techniques.

At the outset, regulators and drafters of ethics codes considered whether to attempt transdisciplinary ethical standards and regulation. The AAA-ABA-SPIDR Joint Standards for the Conduct of Mediators represents an effort to develop such a code for mediators, irrespective of their disciplinary background or training. While the Joint Standards provide a useful starting point for the basic principles of good mediation (self-determination by the parties, impartiality of the neutral, conflicts of interest, basic competency, confidentiality, fees, and solicitation), its vague standards do not provide adequate guidance in particular settings. The Joint Standards, for example, avoid the question "Is ADR the practice of law?" by stating, "A mediator should refrain from providing professional advice."196 This standard provides little guidance for evaluative mediators who increasingly are asked by consumers of ADR services to make predictions, advise about likely court outcomes, or suggest particular outcomes or solutions to problems. ${ }^{197}$

Transdisciplinary ethical standards are desirable because they meet the requirements and outlines of a new profession and recognize potentially different goals than the existing codes. Mediation, for example, is neither therapy, governed by rules affecting psychologists and social workers, nor adversarial representation, governed by the lawyers' rules of professional conduct. Thus, the professional paradigms that inform the existent ethics

196. JOINT STANDARDS, supra note 23 (Standard VI. Quality of the Process, Comments).

197. The Joint Standards do recognize this possibility by suggesting that "[a] mediator who undertakes, at the request of the parties, an additional dispute resolution role in the same matter assumes increased responsibilities and obligations that may be governed by the standards of other professions." Alas, the standards of other professions, like law, also do not speak to these hybrid or more complicated roles of mediator-evaluators or mediators working with pro se parties in terms of duties and potential liabilities for legal advice, information, or predictions imparted. See Purnell, supra note 53; Glen Sato, Comment, The Mediator-Lawyer: Implications for the Practice of Law and One Argument for Professional Responsibility Guidance, 34 UCLA L. REV. 507 (1986); Alison Smiley, Note, Professional Codes and Neutral Lawyering: An Emerging Standard Goveming Nonrepresentational Attomey Mediation, 7 GEO. J. LEGAL ETHICS 213 (1993); see also Robert A. Baruch Bush, The Dilemmas of Mediation Practice: A Study of Ethical Dilemmas and Policy Implications, 1994 J. DISP. RESOL. 1 (documenting the conflicting obligations that come from the complex roles required by mediation); John Feerick et al., Symposium, Standards of Professional Conduct in Altemative Dispute Resolution, 1995 J. DISP. RESOL. 95; Judith L. Maute, Public Values and Private Justice: A Case for Mediator Accountability, 4 GEO. J. LEGAL ETHICS 503 (1991); Leonard L. Riskin, Toward New Standards for the Neutral Lawyer in Mediation, 26 ARIZ. L. REV. 329 (1984). 
codes do not fully reflect the dilemmas faced by third-party neutrals in dispute resolution.

The differences among the processes-facilitative versus evaluative mediation-discussed above reveal even greater complications. While some have suggested that an arbitrator's role is closer to that of a judge given her decision-making power over cases, the Judicial Code of Conduct and specific arbitrator codes ${ }^{198}$ deal with ethical and quality standards issues in arbitration. As I have argued elsewhere, ${ }^{199}$ mediators, who hear confidential settlement facts beyond those which would be heard in more formal, evidentiary arbitration hearings (especially when engaged in caucusing), might be subject to more complex confidentiality and conflict of interest rules when they learn proprietary information from both sides in a dispute. This proprietary information may include financial data, trade secrets, or settlement-based but not legally relevant needs- or interest-based information.

The lawyer's adversarial paradigm simply cannot guide the less adversarial lawyer, both in her role as a third-party neutral, as mediator or arbitrator, or even as a representative within a mediation if a different form of advocacy is required for problem solving than litigation. ${ }^{200}$ To the extent that creative, synthetic, and information-seeking approaches to problem solving are better suited to mediation than argument, debate, and the strategic use of information, then different duties of behavior may be necessary for these different processes to work. In short, problem solving based on different, less adversarial conceptions of both goals and processes cannot be monitored or regulated by ethical standards that assume different foundational and constitutive values. The ethics of advocacy will not adequately guide us for the ethics of problem solving or dispute resolution. To

198. The most well-developed and classic formulation is the AAA ETHICS CODE FOR COMMERCIAL ARBITRATORS (1977).

199. See supra note 190.

200. See Menkel-Meadow, supra note 57. For me, one of the most difficult ethical issues that remains to be considered is the role of representatives in mediation and other forms of ADR when the goal is problem solving and not winner-take-all litigation or even negotiation. The question of whether lawyers should have different and increased responsibilities for candor and fairness outside of the courtroom has been with us for many years. See Murray L. Schwartz, The Professionalism and Accountability of Lawyers, 66 CAL. L. REV. 669 (1978). Some suggest that participation in ADR implicates the ethical standards governing mediators and those governing lawyers who negotiate (principally Rules 4.1 and 4.2 of the Model Rules of Professional Conduct). See COOLEY, supra note 80 , at 147 . But the existing rules on lawyers who negotiate are themselves based on adversarial representative models and do not take account of the potentially different roles for party representatives in problem-solving negotiations or mediations. 
the extent that litigation and mediation represent different cultures, they may require different rules and norms with both official and more informal policing and boundary setting. ${ }^{201}$

At another level of legal pluralism, there are many layers of proposed regulation for ADR. States like Florida have enacted a comprehensive statutory scheme that provides "credentializing" and certification standards for mediators who operate within the state's justice system, as well as formal disciplinary and regulatory bodies. ${ }^{202}$ The proliferation of regulatory standards, ethics codes, and standards of conduct by a variety of professional associations ${ }^{203}$ raises important questions concerning possible overlapping disciplinary jurisdiction and potentially conflicting standards of liability, should courts employ these standards in malpractice or other actions. ${ }^{204}$ Court programs, at both the federal and state levels, have established their own local rules, sometimes including ethical standards or requirements. ${ }^{205}$ Considering the lack of consensus on some of the more controversial issues, there are likely to be difficult choice of law issues as courts and participants attempt to discover which rules and standards apply in certain contexts of dispute resolution practice. ${ }^{206}$

201. I fear that the cultures are blurring in potentially counterproductive ways. Some forms of ADR are increasingly looking like conventional adversarial litigation (arbitration, some forms of evaluative mediation), especially with the growth of "mediation advocacy" courses and books (another oxymoron, in my view). Others have argued that there is too little litigation when it is appropriate, and important cases of clashing values and need for judicial rule making are too often forced to settlement (both in large cases and in smaller, bureaucratically managed cases). See Koniak, supra note 146; Resnik, Failing Faith, supra note 34.

202. . See 5 FLA. STAT. 44.106 (1990); Moberly, supra note 23. As Sharon Press, Director of the Florida Dispute Resolution, says of Florida, "We may not be the best, but we are the most (and often the first)!" (Personal communication, June 6, 1997). Many other states, including Minnesota, Texas, and Massachusetts, have also either begun or completed extensive rule drafting and regulatory schemes for ADR. States like Massachusetts, Virginia, and Florida have formal state offices or bureaucracies that manage dispute resolution processes, some with jurisdiction over the formal court and state justice programs, others with more comprehensive control over dispute resolution services outside of the courts as well.

203. See, e.g., ETHICAL STANDARDS, supta note 23; JOINT STANDARDS, supra note 23; ACADEMY OF FAMILY MEDIATORS, supra note 23.

204. For a comprehensive discussion of confidentiality issues in mediation, see NANCY $\mathbf{H}$. Rogers \& Craig A. MCEWEN, Mediation: LAW, POlicy and Practice (2d ed. 1995).

205. The Northern District of California, for example, has incorporated federal judicial rules of recusal and conflict of interest as its rules for conflicts of interests for court-appointed thirdparty neutrals. See N.D. CAL. R. 2-5(d); PLAPINGER \& STIENSTRA, supra note 23.

206. Again, this problem is not unique to $A D R$. Linda Mullenix has demonstrated that the problem of which ethics rules apply in the federal courts is similarly subject to difficult choice of law and legal pluralism issues. See Linda S. Mullenix, Multiforum Federal Practice: Ethics and Erie, 9 GEO. J. LEGAL ETHICS 89 (1995). 
To illustrate some of the ethical controversies among dispute professionals, I will describe some of the recent issues that I have more fully canvassed elsewhere. ${ }^{207}$ At a threshold level, dispute professionals debate whether third-party neutraling constitutes the practice of law, such that third-party neutrals should be subject to ethics standards, liability rules, or prohibited from practicing if they are not attorneys. ${ }^{208}$ On one side are those who, like me, think that mediators who predict court outcomes, evaluate claims, or discuss strengths or weaknesses of cases are engaged in "applying general legal principles to specific facts," thus implicating legal practice and possibly inducing reliance on this advice. On the other side are those who rest on the formalism of current legal principles or cases and argue that if there is no representational "attorney-client" relationship, then there is no practice of law. In my view, the increasing application of third-party liability to lawyers in other contexts ${ }^{209}$ may soon affect lawyers who give some forms of legal information, prediction, or advice during mediation sessions. If ADR practice is the practice of law, ${ }^{210}$ then the Model Rules of Professional Conduct will be applied in situations in which they may not be fully responsive to the particularities of ADR practice. Even if ADR is not considered the practice of law, growing evidence suggests that courts are using those standards and ethics rules by analogy, if not by direct application.

Of great practical import to the ADR profession is the potential application of attorney conflict-of-interest rules to the practice of ADR. In a series of recent cases, courts have begun to grapple with difficult situations in which partners of some law firms practice conventional representational law while others mediate or arbitrate, or with single lawyers who perform

207. See supra note 194.

208. See Menkel-Meadow, supra note 194; Meyerson, supra note 51 (arguing that because mediators do not "represent" parties in mediation, they have no clients and are therefore not practicing law). A Virginia court has just held that a non-lawyer who offered to advise the parties of their legal rights and prepare a settlement agreement, in a court connected program was engaged in the unauthorized practice of law. See Geetha Ravindra, ALTERNATIVES (forthcoming 1997). Similarly, the Florida Mediation Qualifications Advisory Panel has recently ruled that a mediator may not give any legal advice, see supra note 51 . Lawyers may always be disciplined (including disbarment) for their activities in non-legal roles if their behavior constitutes a violation of the applicable disciplinary rules.

209. See Symposium, The Lawyer's Duties and Liabilities to Third Parties, 37 S. TEX. L. REV. 957 (1996).

210. Geoffrey Hazard, reporter for the Kutak Commission's Model Rules and current director of the American Law Institute, has opined that lawyers who mediate are engaged in ancillary practice under MRPC 5.7 and thus are governed by the Model Rules. See Geoffrey C. Hazard, Jr., When ADR is Ancillary To A Legal Practice, Law Firms Must Confront Conflicts Issues, 12 ALTERNATIVES 147 (1994). 
both roles themselves. In Poly Software International v. $\mathrm{Su}^{211}$ a lawyer mediated a dispute between a computer software company and two of its employees who were accused of copyright violations. The matter settled and the two employees later formed their own new entity. Subsequently, they were engaged in a similar claim of software misappropriation against each other, and one of the parties sought representation from the lawyer who had previously mediated their dispute. The court, reasoning by analogy, applied the dictates of Model Rule $1.9^{212}$ and held that the mediator (and no one in his firm) could not represent a party in an adverse proceeding in which he had previously participated in a mediation with that party and his adversary. The court reasoned that the mediator had likely learned of confidential information, which harmed the appearance of "neutrality" when he aligned himself subsequently with one of the parties.

In another case, Cho v. Superior Court, ${ }^{213}$ the court disqualified a law firm because a judge, who had previously attempted settlement discussions with two parties to a bank dispute, subsequently joined the law firm that represented one of the parties. The court refused to allow the screen or cone of silence permitted under the equivalent of Rule 1.12 for judges who subsequently return to practice because the judge had learned confidential information from the adverse side in individual (caucus-like) meetings. The court was also concerned about the "appearance of impropriety" should the case be viewed by outsiders who would see a former neutral joining forces with a partisan. ${ }^{214}$ Some have criticized this case ${ }^{215}$ because mediators and judges, more than practicing lawyers, promise confidentiality to parties in mediations (usually by contract, but also by court rule ${ }^{216}$ ) are thus not permitted to discuss their cases with other members of a firm and thus, would seem to be most appropriate for permissible screening. Thus, some practitioners urge that ADR standards should permit screening an individual with a conflict of interest due to prior third-party neutraling work so

211. 880 F. Supp. 1487 (D. Utah 1995). See also McKenzie Const. v. St. Croix Storage Corp., 961 F. Supp. 857 (D.V.I. 1997) (involving a party-hired mediator who subsequently joined one party's law firm and was disqualified).

212. MODEL RULES OF PROFESSIONAL CONDUCT Rule 1.9 (1983) (applying to lawyer representation in prior matters).

213. 45 Cal. Rptr. 2d 863 (1995).

214. In a more obvious case, a state court reversed a criminal conviction in which the prosecutor had previously been involved in mediation efforts in the same matters. See State v. Tolias, 929 P.2d 1178, 1181 (Wash. 1997) (holding that the functioning in two roles "created an appearance of unfairness").

215. See James Mcguire, Conflicts in Subsequent Representation, DISP. RESOL. MAG., Spring 1996 , at 4.

216. See MOdel Rules of Professional CONDUCt Rule 1.12 (1983). 
that law firms may simultaneously engage in adversarial representational practices, as well as third-party neutraling. ${ }^{217}$ I have argued that this solution is problematic because of the different nature of information learned by some ADR practitioners. Mediators, for example, are often privy to "settlement facts" that include proprietary trade secrets, financial information, and interest-based information about the parties. Thus, a mediator could possess information about a potential adversary in a representational context that could be quite damaging. ${ }^{218}$ Thus, conflicts of interest in the ADR setting present both analogous and somewhat different considerations than those that exist for attorneys in conventional representation. When single lawyers or different lawyers within law firms change roles as well as clients, the kinds of conflicts (in terms of information received and perceptions of neutrality or partisanship) may call for different standards. Those who want to encourage the joint enterprise of representational services and neutraling services within the same firm are likely to urge permissive (client "consentable" or waivable conflicts, screens for imputed conflicts, and narrow "matter" definitions ${ }^{219}$ ) conflicts rules. ${ }^{220}$

For those concerned about the appearance of impropriety in role switching (that is, from neutral to partisan) as well as party switching, more restrictive rules might be appropriate. Many who desire more restrictive rules are concerned about the general integrity of the profession and its appearance to the larger public when conflicts appear to be permitted. ${ }^{221}$

217. The screen or cone of silence is generally reserved for government lawyers or judges who return to practice and are screened from fees, information, and files involving parties involved in matters from their former roles. A few courts have permitted (by common law development and not usually by rule) screens to be used more generally in lateral law firm moves of lawyers who would otherwise bring the conflicts taints of the cases handled by their former law firms. See Thomas D. Morgan, Screening the Disqualified Lawyer: The Wrong Solution to the Wrong Problem, 10 U. ARK. LTTLE ROCK L.J. 37 (1987). Pennsylvania allows screening in its equivalent of Rule 1.10. The recent draft of the Restatement of the Law Governing Lawyers includes a broader screen provision for certain classes of conflicts. See RESTATEMENT OF LAW GOVERNING LAWYERS § 204 (Proposed Final Draft, March 29, 1996). Many ADR practitioners would like to see some version of this broader screen used in the ADR context.

218. Rule 1.9(c) prevents the use of any information received in a prior representation by a lawyer who is permitted to engage in subsequent litigation that has been consented to by the client; some urge that an equivalent protection in an ADR-specific rule would be enough.

219. In the conflicts area, characterizations of matters as "the same or identical," "substantially related," or "unrelated" often determine both the permissibility of the representation and the need for client consent to an otherwise conflicted representation.

220. See Menkel-Meadow, supra note 57.

221. For these issues about the permissiveness or restrictiveness of conflicts rules, including when client consent is necessary, when screens should be permitted, and when lawyers should be allowed to be lawyers for the situation remain controversial in other areas of legal practice as well, see, for example, Nancy Moore, Restating the Law of Conflicts: It Was Necessary, It Will Be 
The CPR-Georgetown Commission on Ethics and Standards in ADR, among other groups, is currently studying these questions and drafting potential rule amendments, both for existing lawyer codes and for freestanding $\mathrm{ADR}$ ethics rules. ${ }^{222}$

Beyond the highly technical and complicated disputes about how conflicts rules should be drawn, there exist other differences among dispute professionals. Early ADR ethics codes usually prohibited contingent fees ${ }^{223}$ in ADR proceedings because of a concern that such payment schemes would produce coerced settlements and give the mediator too much of an incentive to force agreement over a supposedly consensual process. Recently, however, even this issue has become controversial as successful mediators claim "a piece of the action" in successful settlements. 224

Mediators often seek to work in interdisciplinary teams, with psychologists, accountants, social workers, economists, and/or lawyers. To the extent that fee splitting and unauthorized practice of law rules ${ }^{225}$ seem to prohibit such practices, lawyer-mediators fear being subjected to disciplinary proceedings for what ought to be recognized as a superior multi-disciplinary way of working.

Although some lawyers (as dispute resolution professionals) have resisted efforts to require them to apprise clients of the availability and possibilities of "appropriate" forms of dispute resolution beyond litigation, a

Helpful and We Mostly Got It Right, GeO. J. LEGAL ETHICS (1997); see also Menkel-Meadow, Ethics and Settlements, supra note 146.

222. See Menkel-Meadow, supra note 57, for some draft rule proposals.

223. Contingent fees are based on percentages of the settlement amount or a "settlement bonus" to be paid when agreement is reached.

224. Kenneth Feinberg, who is an active participant in most of the major mass tort actions, including Dalkon Shield, Asbestos, and now tobacco, remarked at the April 29, 1997 ADR Superconference in Washington, D.C., that he has often received such payments. Feinberg suggests that skilled mediators can use such fee arrangement to motivate parties (especially reluctant parties) to participate in processes when they are often quite skeptical. More common fee arrangements include a floor of either hourly rates for preparation and initial meetings, retainer or fixed rates for some period of time, and then some bonus payment if settlement is achieved. Many mediators complained that their hourly rates were often fractions of what the representational lawyers were earning in sitting in on the same sessions (and, they would argue, doing less work).

225. MODEl Rules of Professional CONDUCt Rule 5.5 (1996). 
growing number of states have required, either by formal rule or by ethics opinion, that lawyers inform their clients about different forms of dispute resolution, either when they are suggested by the other party, or as an independent obligation. ${ }^{226}$ Thus, lawyers will increasingly have to understand and embrace ADR enough to inform clients concerning the advantages such processes offer over more conventional forms of litigated solutions to problems. These rules and ethics opinions themselves raise important questions about whose role it will be to decide what process should be used in solving a legal problem, ${ }^{227}$ and may require even the most adversarialist lawyer to become conversant with ADR.

In addition to the ethics issues that confront any profession, dispute resolution professionals currently face a variety of interesting and potentially conflictual issues that are somewhat particular to the profession. Since the modern rediscovery of mediation-like processes, third parties have debated whether mediators ought to be partially accountable or responsible for the outcomes they oversee. The now classic expression of this debate occurred in considering whether public policy mediators have responsibilities (in such matters as environmental, siting, community, and budget disputes) to insure the fairness of outcomes or agreements reached by the parties and to consider absent third parties who might be affected by any agreement reached. ${ }^{228}$ Larry Susskind has argued eloquently that mediators do have additional accountability and responsibilities for the outcomes they facilitate and to parties who might be affected by the

226. See Garwin, supra note 84, at 84 (citing Pennsylvania Bar Ass'n Ethics Op. 90-125); see also Jackson v. Philadelphia, 858 F. Supp. 464 (E.D. Pa. 1994); COLO. RULES OF ProfESSIONAL CoNDUCT Rule 2.1 (1996); Kan. Bar. Ass'n Comm. on Ethics-Advisory Services, Op. 94-01 (1994); Mich. State Bar Comm. on Prof'l and Judicial Ethics, Informal Op. RI-255 and RI-262.

227. See MODEL RULES OF ProfessionAl CONDUCT Rule 1.2 (1996) (directing that lawyers are to abide by a client's decisions concerning objectives of representation, including whether to accept a settlement offer). Are process choices part of the objectives or settlement offers of representation? See Robert F. Cochran, Jr., Legal Representation and the Next Steps Toward Client Control: Attomey Malpractice for the Failure to Allow the Client to Control Negotiation and Pursue Altematives to Litigation, 47 W ASH. \& LEE L. REv. 819 (1990); see also Carrie Menkel-Meadow \& Beatrice Moulton, Who Decides? Lawyer-Client Decisionmaking About Dispute Resolution (1989) (unpublished manuscript, on file with author).

228. Economists would suggest that mediators should consider not only the efficiency of agreements reached but should also consider the externalities that the parties might be imposing on non-present parties. See Brown \& Ayres, supra note 114; Luban, supra note 8. 
solutions. ${ }^{229}$ On the other side, Joseph Stulberg has argued that mediators have no special responsibility, for the agreement belongs solely to the parties and, if they agree, that is sufficient. ${ }^{230}$

To the extent that mediators in court settings receive quasi-judicial immunity, ${ }^{231}$ which seems to include actions taken within the mediation or court-related functions, as well as for outcomes, it remains an unsettled question as to who will monitor ADR processes. With mediators disclaiming responsibility for the outcomes they facilitate and courts holding them harmless (at least in court settings), mediators may be subject to very little review or control over what they do. ${ }^{232}$

Mediators also differ in situations in which there is unequal power or resources in mediation. In several specific areas, some have urged that mediation should never be used, or used only with extreme caution, when the parties have grossly disparate economic, social, political, gender, or racial resources. ${ }^{233}$ To correct these inequalities, mediators employ certain techniques to balance power between the parties and correct for information inequalities, such as by sharing information or giving legal advice, by using role-reversal techniques, by recommending the use of outside experts or representatives, and by meeting in separate sessions to provide information, learn of underlying needs, and so forth. ${ }^{234}$ Others urge particular techniques for cultural balancing in cross-cultural disputes. ${ }^{235}$ Yet, to the extent that some feel that power-balancing

229. See Susskind, supra note 18. This is an argument that has been extended by some to the field of divorce mediation, in which some urge that mediators have a responsibility to consider the effects of any agreement on the children. See JUDITH S. WALLERSTEIN \& JOAN B. KELlEY, SECOND CHANCES (1990); JUDITH S. WALLERSTEIN \& JOAN B. KELLEY, SURVIVING THE BREAK-UP (1980).

230. See Stulberg, supra note 18.

231. See Wagshal v. Foster, 28 F.3d 1249, 1254 (D.C. Cir. 1994); Meyers v. Contra Costa County Dep't of Soc. Servs., 812 F. 2d 1154, 1158-59 (9th Cir. 1987); Howard v. Drapkin, 222 Cal. App. 3d 843, 852-53 (1990).

232. Although many think that arbitrators have very limited accountability, given the strict standards of reviewability under the Federal Arbitration Act, 9 U.S.C. $\$ 10$ (1994), and the states' equivalents in the Uniform Arbitration Act, there are, in fact, no statutory standards for review of mediated agreements. Agreements are judged, if at all, by substantive contract principles-to void a mediation a party would have to attack the validity of the agreement made (or seek some more general public policy ground for appeal or review). In private mediation, the only regulatory or accountability may be market discipline.

233. See, e.g., Delgado et al., supra note 193; Grillo, supra note 7.

234. See MARK D. BENNETT \& MICHELE S.G. HeRMANN, THE ART OF MEdIATION 118-22 (1996); see also JONATHAN SHAILOR, EMPOWERMENT IN DISPUTE MEDIATION: A CRITICAL ANALYSIS OF COMMUNICATION (1994).

235. See BENNETT \& HERMANN, supta note 234, at 115-17; MYERS \& FILNER, supra note 192; Gunning, supra note 193. 
techniques are appropriate to make mediation fair (and to engage in the same sort of behavior that suggest judges use to equalize power in the courtroom $\left.{ }^{236}\right)$, it is also true that many mediators feel that such activity compromises the neutrality of the mediator.

Thus, behavioral variations and techniques in mediation are layered with philosophical, jurisprudential, and ethical differences and consequences. Some suggest, therefore, that only micro (behavioral) ethical issues can be regulated and the macro (fairness of process and outcome) justice issues must be left to party choice and philosophical dispute. I believe these micro behavioral choices are so deeply connected to larger ethical and justice concerns that we cannot possibly regulate behavior without having a deeper sense of what our ethical mandates are. While one solution is to present different layers of ethical choice-from aspirational, affirmatively stated "best practices" standards, to more specific and negative specifications of consensually arrived at "bad practices" in clearly stated prohibitory rules ${ }^{237}-$ it is clear that there is no consensus on some of these important issues. For this reason, some would prefer a simple obligation of disclosure describing mediators' particular practices with adequate information guiding party choice. It remains to be seen whether this market discipline mechanism will be enough, as parties either choose or are required to use ADR when they do not fully appreciate the procedures or consequences of their "allocated" process.

Finally, courts or contracts often mandate ADR referral to particular provider organizations or rosters, thus raising the possibility of collective or organizational standards, ethics, and liability. ${ }^{238}$ Recently, several provider organizations developed and signed an important organizationally imposed code called the Due Process Protocol for Employment Disputes. ${ }^{239}$ In addition, some major providers, like JAMS-Endispute, have developed their own organizational and internal protocols and standards, which are internally policed and distributed to clients. ${ }^{240}$ At

236. See Fiss, supra note 9, at 1076-79.

237. See, for example, the former division of aspirational "Ethical Considerations" from Disciplinary Rules in the older Model Code of Professional Responsibility. See also Murray Schwartz, The Death and Regeneration of Ethics, 1980 AM. B. FOUND. RES. J. 953.

238. See genetally NATIONAL STANDARDS FOR COURT-CONNECTED MEDIATION PROGRAMS (Center for Dispute Settlement and Institute of Judicial Administration).

239. See supra note 66 . This protocol has been signed by the AAA, the National Employment Lawyers Association, the Federal Mediation and Conciliation Service, the ABA Employment and Labor Law Section, the ACLU, and a variety of other providers of ADR services.

240. See JAMS-ENDispute Due Process Protocol and CODE of Ethics (1996); Great Western Mortgage Corp. v. Peacock, 110 F.3d. 222 (3d Cir. 1997). 
least one commentator has suggested that collective entities, like law firms, should bear responsibility for their members' ethical violations. ${ }^{241}$ Similarly, when large providers develop "brand-name" recognition for ADR services, it may be that provider organizations ought to be subject to ethical standards (and may ultimately be subject to organizational liability ${ }^{242}$ ) for quality control or claims about the services they provide. Given the wide variety of provider entities, this may indeed be a difficult project. ${ }^{243}$

Even though dispute professionals seek to create a creative, flexible, well-meaning, and self-regulating profession, it is now clear that increased use of ADR has raised these issues of quality control, ethical standards, accountability, and liability. As dispute professionals resolve their own issues of ethics and standards from within, consumers of ADR services seek to determine if ADR really satisfies their needs and supports the claims it makes for itself. As the internal debates productively continue, they are now joined by disputes, disagreements, and conflicts from those who would evaluate and regulate ADR from outside. It is to these disagreements about dispute resolution evaluation that I now turn.

\section{EVAluATIONS OF ADR: DOes IT WORK? FOR WHAT PURPOSES?}

Since the introduction of modern ADR forms in both the courts and private sector, proponents of ADR have offered different rationales and arguments for its use, while opponents of ADR have countered with a variety of objections. The variations in objectives and justifications for ADR (efficiency or quality) have made measurement of its claims quite difficult, with substantial differences in the outcomes of empirical studies of satisfaction with, or the cost effectiveness of ADR. The question of whether ADR is to be justified by the cost and time savings it arguably provides, or whether it promotes better case resolution by allowing more flexible and individually crafted solutions to problems, present totally different evaluative criteria in designing evaluations.

In recent months, two major studies of ADR in the federal courts ${ }^{244}$

241. See Ted Schneyer, Professional Discipline for Law Firms?, 77 CORNELL L. REV. 1 (1991).

242. See Olsen v. American Arbitration Ass'n, Inc., 876 F. Supp. 850 (N.D. Tex. 1995).

243. The CPR-Georgetown Commission on Ethics and Standards in ADR has a Working Group on Provider Organizations which is developing a Protocol for Organizational Disclosures and a Consumer Checklist for selecting provider organizations. Developing a taxonomy of provider organization types is also one of the Commission's goals.

244. See RAND ADR REPORT, supra note 26 (evaluating six courts' mediation and early neutral evaluation programs); RAND CASE MANAGEMENT REPORT, supra note 26 (evaluating ten pilot and ten comparison courts under the Civil Justice Reform Act); FJC REPORT ON ADR, 
have demonstrated the lack of consensus, both about how to evaluate ADR and how to understand the evaluations. Although I will offer my own critiques and views below, it is possible to summarize some of what we know now.

In some sense, the RAND studies validate some of the early findings of Maurice Rosenberg with respect to certain forms of early case management interventions. The RAND studies substantiate that early trial dates and early discovery cut-offs may do more to decrease case processing time than extensive judicial case management. ${ }^{245}$ The studies, however, are less helpful with respect to conclusive findings about ADR. Though the RAND studies seem to indicate little or no cost or time savings from arbitration, mediation, and early neutral evaluation programs in the federal courts that were studied, ${ }^{246}$ the Federal Judicial Center did find some cost and time savings in at least two of the districts it studied. ${ }^{247}$ To further complicate these issues, virtually all studies of arbitration and mediation programs in both federal and state courts reveal high participant and attorney satisfaction rates with ADR. ${ }^{248}$

supra note 26 (studying five demonstration courts); see also The RAND Report and Federal Court ADR, DISP. RESOL. MAG., Summer 1997, at 3-20.

245. See Maurice Rosenberg, The Pretrial Conference and Effective Justice: A CONTROLLED TEST IN PERSONAL INJURY LITIGATION (1964) (finding that it was the setting of a definite and early trial date and not the occurrence of judge-led settlement or pretrial conferences that was likely to decrease time to disposition). The RAND study on case management techniques used pursuant to the Civil Justice Reform Act found that case processing time could be decreased with early judicial case management, setting the trial schedule early, shortening discovery time and having litigants present or available for settlement conferences, although early judicial case management was also associated with increased costs. The RAND Case Management study also found that if early case management and early trial setting were combined with early discovery cut-offs the increase in costs associated with increased attorney work hours could be offset. On the other hand, one of the more significant effects on case time disposition was the simple requirement that the status of each judge's calendar is now reported every six months. Although civil case filings increased during the period of study (1991-1995), cases pending for over three years declined by $25 \%$ following this reporting requirement. Thus, simple and "transparent" court reforms may have the greatest effects on court backlog and dockets. For a review of empirical literature on effectiveness of settlement conferences, see Menkel-Meadow, supra note 100 , at 493-98.

246. See RAND ADR REPORT, supra note 26 (studying mediation and early neutral evaluation programs in six programs that generated enough cases for empirical measures to be statistically significant); RAND CASE MANAGEMENT REPORT, supra note 26 (studying case management devices, including arbitration).

247. The two districts are the Western District of Missouri and the Northern District of California.

248. See, e.g., E. Allan Lind et Al., The Perception of Justice: TORT Litigants' VIEWS OF TRIAL, COURT ANNEXED ARBITRATION AND JUDICIAL SETTLEMENT CONFERENCES (1989); Marc Galanter \& Mia Cahill, "Most Cases Settle": Judicial Promotion and Regulation of Settlements, 46 STAN. L. Rev. 1339 (1994); Lind et al., supra note 93. 
In contrast to the many court-connected program evaluations, however, there is little to no information concerning the private uses of $\mathrm{ADR}^{249}$ in large part because developing anything close to an experimental or comparative design model is virtually impossible. ${ }^{250}$

Research concerning the effects of ADR programs is especially difficult due to the problems of developing control groups; indeed, how can one case be subjected to both ADR and litigation? When attempts have been made to study the effects of ADR in the aggregate, ${ }^{251}$ groups of cases ${ }^{252}$ are collected by case type, amount in controversy, and type of process. But, as we have seen from the descriptions above, the process types (arbitration and mediation) may be lumped together for aggregate analysis and may not fully reflect process differences. For example, in the RAND study of mediation and early neutral evaluation, which found no statistically significant cost or time savings from mandatory or voluntary mediation and early neutral evaluation programs in six courts, the courts varied in how they conducted mediation, and at least one court changed its program during the study because its own internal evaluation revealed that mediations were

249. See Janice Roehl, Private Dispute Resolution, in Susan Keilitz, NATIONAL SyMPOSIUM ON COURT-CONNECTED DISPUTE RESOLUTION RESEARCH (1994). See also Rolph et al., supra note 43; Kenneth Kressel, Practice-Relevant Research in Mediation: Toward A Reflective Research Paradigm, 13 NegotiATION J. 143 (1997).

250. Court programs permit a greater likelihood of developing something close to a control group when researchers can match case types, amounts in controversies, types of courts, and so forth. Although I criticize some of this matching strategy, it is at least possible to attempt construction of such data sampling in the controlled universe of cases filed with courts. Such matching of case types to contrast different treatments (arbitration, mediation, litigation) are virtually impossible when one seeks to capture cases processed in the private sector. There have been some excellent studies within particular domains of case types by private providers who have permitted study. See, for example, Bingham, supra note 130, for an excellent series of studies of labor and employment arbitration conducted under the auspices of the AAA. Other private entities have been resistant to study. The Institute of Social Analysis attempted a rigorous study of private judging in California some years ago (I served on the Advisory Committee for the study), but data collection from private entities such as JAMS was very difficult. Private ADR organizations remain quite proprietary about their operations, thus fueling the flames of those who would contest the effects of privatization of the justice system.

251. See Craig MCEwan, Evaluating ADR PROGRAms IN Emerging Issues IN STATE AND FederAl COURTS (Frank Sander ed., 1991); John P. Esser, Evaluations of Dispute Processing: We Do Not Know What We Think and We Do Not Think What We Know, 66 DeNV. U. L. REV. 499 (1989) (reviewing empirical studies and literature on dispute processing as of 1988).

252. As with the RAND, FJC, and many state court studies. For a good review and summary of state court research on ADR, see NATIONAL SYMPOSIUM ON COURT CONNECTED DISPUTE RESOLUTION RESEARCH (Susan Keilitz ed., 1994). 
occurring prematurely. ${ }^{253}$ Furthermore, these aggregate studies often cannot distinguish between facilitative or evaluative models because they do not examine what actually occurs inside the ADR session. ${ }^{254}$ Finally, variations in the practices of $A D R$ programs within the courts often makes comparison difficult. The Eastern District of Pennsylvania, for example, limited mediation to one hour (with mediators hearing three cases on one day ${ }^{255}$ ), whereas mediation programs in other courts, such as the Western District of Missouri and the Northern District of California, allowed longer time periods and were more likely to have more than one session. ${ }^{256}$ Also, in some court programs, mediators have extensive training in mediation as well as litigation experience; in other courts, mediators are generally untrained and placed on a court roster because of their litigation experience or activity in bench and bar activities.

Thus, like others, ${ }^{257}$ I am concerned that large aggregate studies often mask important and subtle differences between courts and their programs that do not present an adequate indication of what programs actually do-including both the cost and efficiency concerns and the more difficultto-measure qualitative issues. ${ }^{258}$ The RAND methodology is illustrative of these issues: ten pilot courts were expected to develop and utilize

253. The Eastern District of Pennsylvania changed its "mandatory mediation" program before the parties had adequately prepared their cases and knew what the issues were to mediate. See RAND ADR REPORT, supra note 26, at 91-122.

254. See id. at 94.

255. See id. at 93 . This was modeled on the court's mandatory arbitration program which has been in existence since 1978. See MEIERHOEFER, supra note 93, at 14; MENKEL-MEADOw, supra note 111 .

256. See FJC REPORT ON ADR, supra note 26.

257. See CPR Judicial Project Advisory Council, Statement of Concems Regarding the RAND ADR Study (March 14, 1997) (to which I was a signatory). See also Elizabeth Plapinger, RAND Study of Civil Justice Reform Act Sparks Debate, NAT'L L.J., Mar. 24, 1997, at B-18; John Gibeaut, Was RAND Right?, A.B.A. J., May 1997, at 98; Stephanie B. Goldberg, RAND-ly Criticized, A.B.A. J., Apr. 1997, at 14; The RAND Report and Federal Court ADR, supra note 244; Craig McEwen \& Elizabeth Plapinger, RAND Report Points Way to Next Generation of ADR Research, DiSP. RESOL. MAG., Summer 1997, at 10.

258. In a recent article, even Deborah Hensler, Director of the Institute for Civil Justice at RAND, acknowledged that certain case types may benefit more from ADR than others (a possibility that the RAND data have not been used to interrogate), that values other than efficiency (in case time disposition and costs) may inform ADR, and that the RAND "CJRA evaluation did not address such issues." See Deborah Hensler, Puzzling Over ADR, 5 (1) Facts and Trends: Institute for Civil Justice (April, 1997 at 6). See also Francis E. McGovern, Beyond Efficiency: A Bevy of ADR Justifications, DISP. RESOL. MAG., Summer 1997, at 12; Jeffrey G. Kichaven, ADR Does Not Save Time or Money? Great News!, DISP. RESOL. MAG., Summer 1997, at 15. 
methods suggested by the Civil Justice Reform Act for case management, which included judicial case management, case tracking, discovery reforms, and referrals to ADR. The comparison groups also began (although at a later date) implementing some of these reforms and in some cases, comparison courts had more active programs than pilot courts. ${ }^{259}$ Thus, given the on-going change during the study period, variations within, in addition to between courts may mask or obscure the full story of legal change. ${ }^{260}$

Even with these flaws, the recent studies have produced some useful information about ADR. The RAND ADR study found that money is more likely to change hands in mediation programs and that settlements, either immediately before or during the ADR sessions, are more likely to happen when the ADR procedure occurs later in the process, telling us

259. It is also true, however, that many of the courts (on both sides of the pilot/comparison divide) claimed either to have done nothing in response to the CJRA (complaining of congressional interference in judicial matters), or claimed that they were actively engaged in case management before CJRA took effect, thus making the findings of the report-no significant effects from CJRA activities-explainable by the lack of differences before and after CJRA took effect. Whatever the researchers' responses to these somewhat inconsistent claims, it is likely that the study was dealing with several moving targets-some courts that did nothing to change but already were utilizing $A D R$ and case management techniques, some courts that responded vigorously to CJRA requirements (on both sides of the pilot and comparison divide), and other courts that did little at all. In addition to these concerns, whatever the official policy at the district court level, promulgated in local rules resulting from meetings of each district's CJRA Advisory Committee, see Linda S. Mullenix, The Counter-Reformation in Procedural Justice, 77 MINN. L. REV. 375 (1992); Linda S. Mullenix, Unconstitutional Rulemaking: The Civil Justice Reform Act and Separation of Powers, 77 MINN. L. REv. 1283 (1993); Lauren K. Robel, Fractured Procedure: The Civil Justice Reform Act of 1990, 46 STAN. L. REV. 1447 (1994); Lauren K. Robel, Grass Roots Procedure: Local Advisory Groups and the Civil Justice Reform Act of 1990, 59 BROOK. L. REV. 879 (1993), individual judges often set their own policies with respect to ADR, discovery, and case-management techniques by memorandum orders and data at the court, not individual judge, level.

260. In a comprehensive, rather than "representative sample," description of what federal courts have actually been doing in the ADR area, Elizabeth Plapinger and Donna Stienstra have documented that almost every district court attempted some kind of ADR process with enormous ranges of differences among them. "By 1996, 51 district courts had established mediation programs . . . 14 districts were operating court-annexed neutral evaluation programs, 22 courts were using court-annexed arbitration programs and settlement weeks and other hybrid programs were in place in five other districts." PLAPINGER \& STIENSTRA, supra note 23, at 14-17. The programs chosen by RAND for study (of ADR, unlike the case management courts) were not representative. They were chosen because they were: (1) already in the study, and (2) had sufficient cases for statistical analysis, but they represented less than $10 \%$ of all federal court programs and were hardly typical. As indicated above, the Pennsylvania mediation program changed over time and recognized its own flaws during the study period: Several courts required party consent for ADR referral and others mandated participation; some involved judge choice, others did not, and some referrals occurred early and others late. Thus, the programs had enough variations among them that, although compared with non-ADR cases from within their own districts, there are sufficient variations in these programs without substantial enough numbers for the researchers themselves to conclude that any significant policy decisions can be based on these data. 
something about the settlement dynamics of mediation when used in court programs. ${ }^{261}$ The RAND researchers also found that ADR is most likely to be utilized in mandatory and well-administered programs than in voluntary and loosely structured programs. ${ }^{262}$ In addition, the Federal Judicial Center study documents some cost and time savings in at least two courts with well-designed and professionally administered programs. ${ }^{263}$

At the present time, I think researchers develop the best data sets from well-constructed single-court studies. ${ }^{264}$. In my experience of evaluating one court's arbitration program, ${ }^{265} \mathrm{I}$ found that in-depth studies of the "local legal culture" can reveal more about the usage of a program than aggregate data sets. ${ }^{266}$ For example, the use of arbitration in the federal

261. See RAND ADR REPORT, supra note 26, at xxiii.

262. Indeed, the usage of voluntary programs was often so low that there was insufficient data to study such programs. Findings such as these have affected my own view about whether court ADR programs should be mandatory or not. Though I have often been identified as approving only of voluntary programs, see Menkel-Meadow, supra note 110 , I have come to the view that as long as agreement or settlement is not required, a presumptively mandatory referral to some form of ADR (preferably, but not necessarily with party choice) helps educate the lawyers and parties about other ways to resolve cases and focuses attention on cases in different and perhaps productive ways. As long as there is the possibility of a trial de novo in decisional ADR (like courtconnected arbitration), then jury trial rights are not compromised. In my study of the Eastern District of Pennsylvania, I found no evidence that indigent litigants were disadvantaged by the court's arbitration program. Indigents can utilize in forma pauperis procedures to avoid posting arbitrator costs for de novo appeals. Many case types involving indigents are excluded from the program (civil rights, prisoner cases, and social security cases), and personal injury cases involving indigents, as with other litigants, are virtually always conducted on a contingent fee basis, so that most of Lisa Bernstein's concerns about the effects of court-annexed arbitration on indigent litigants do not seem to be borne out by the data. See Bernstein, supra note 10 . The greatest threat to access for indigent litigants in the federal courts is not ADR processes, but restrictive federal jurisdictional changes (such as the recent increase in diversity jurisdiction to $\$ 75,000$ ).

263. See FJC REPORT ON ADR, supra note 26; Rosenberg \& Folberg, supra note 23; KENT

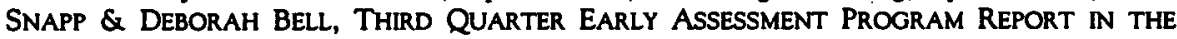
WESTERN DISTRICT OF MISSOURI (1996); Kent Snapp, Five Years of Random Testing Shows Early ADR Successful, DiSP. RESOL. MAG., Summer 1997, at 11.

264. See, e.g., Rosenberg \& Folberg, supra note 23.

265. A court that was one of the pilot courts studied by RAND. In this evaluation, methods used included interviews, focus groups, case disposition statistics, and questionnaires of program users. See MENKEL-MEADOW, supra note 111.

266. Like others who have been concerned with the RAND studies, I have no doubt that the Judicial Conference and RAND attempted to carefully select pilot and comparison courts, looking at such factors as district size, workload per judge, number of civil and criminal filings, and the time to disposition in civil cases. See RAND CASE MANAGEMENT REPORT, supra note 26, at 15. But because I am familiar (through both practice and research) with several of the matched courts, I am concerned that other local legal cultural factors may define differences in the courts that are masked by aggregation of data. For example, case types vary enormously and researchers had to decide whether, for example, to treat the large asbestos caseload in Philadelphia separately for the analysis (as the presence of this caseload very much affects the way in which cases may be managed and other cases may be disposed of). There are similar regional differences in case types, attorney practice routines, and other legal cultural variables. For examples of differences among 
court I studied mirrored the local state court culture in which arbitration has been used for over forty years, thus providing an environment in which lawyers understood how it worked and appreciated its benefits. Lawyers in the Eastern District of Pennsylvania, for example, overwhelmingly supported their federal court arbitration program, ${ }^{267}$ not only because of its perceived efficiencies and fairness, but because of the educational benefits it provides, both for young lawyers who learn how to try cases and for arbitrators who become better litigators by serving as adjudicators. Of course, because we all seek information to identify general patterns, small-scale, court-based studies may not fully satisfy our desire to learn more about how $A D R$ is working generally. However, in my view, given the relative newness and diversity of ADR programs, I think it is unlikely we will find much in the way of aggregate overall patterns. As at least one set of commentators has noted, settlement as a process cannot be evaluated as good or bad in the aggregate-there are good and bad settlements, just as there are good and bad litigated outcomes. ${ }^{268}$

Along with other researchers, I do think it is time to focus on a second generation of research questions with respect to ADR. Because I have never believed that ADR would or even should be a panacea for court

local legal cultures (including regional variations and variations between federal and state practitioners), see WaYNe D. BrazIL, SeTtLING CIVIL SuITS: LITIGators' Views about APPROPRIATE ROLES AND' EFFECTIVE TECHNIQUES FOR FEDERAL JUDGES (1985) (finding that there are regional differences in lawyer preferences for judicial intervention in settlement, often based on state court practices); UTZ, supra note 179 (finding significant differences in criminal case types in two districts in the same state, resulting in different patterns of plea bargaining and case processing); JONATHAN M. HYMAN ET AL., CIVIL SETTLEMENT: STYLES OF NEGOTIATION AND DISPUTE RESOLUTION (1995) (studying geographic differences within one state of lawyer negotiating styles); THOMAS CHURCH et AL., JUSTICE Delayed: THE PACE OF LIMIGATION $\mathrm{N}$ URBAN TRIAL COURTS (1978) (finding that local legal culture is strongest explanatory factor in understanding patterns of case processing in different courts); Thomas W. Church, Jr., The "Old and the New" Conventional Wisdom of Court Delay, 7 Just. SYS. J. 395 (1982).

267. Although the RAND researchers found no statistically significant effects of arbitration (in three programs with court-mandated arbitration) on time to disposition, lawyer work hours, or lawyer satisfaction, in my evaluation of the Eastern District of Pennsylvania there was overwhelming approval and satisfaction with the program, finding that over three-fourths of all attorney respondents approved of the program and over $60 \%$ of the respondents preferred arbitration over other forms of case processing. See MENKEL-MEADOw, supra note 111. There were no differences in approval ratings between plaintiff- and defendant-identified attorneys. In developing one measure of costs, attorneys reported that arbitration costs (including attorney time and expenses) were from one-third to one-half as much as trial costs (based on attorney self-reports for a six-month period of reported arbitration and appealed cases). This measure, of course, does not compare arbitration to settlement costs, except in cases that settled after the arbitration.

268. See Galanter \& Cahill, supra note 248. 
delay, ${ }^{269}$ I think we should focus our research attention on other issues, such as: differences in mediator and arbitrator styles; party expectations of and satisfaction with different processes; the relationship of private ADR processes to public court-annexed programs; ${ }^{270}$ differences in attorney style and approaches to different forms of ADR; incentives that affect the kind of process choice; preparation and strategies that are used in case processing; ${ }^{271}$ the extent of monetization or nonmonetization of dispute settlements in different disputing environments; and the many difficult issues spawned by claims that ADR is less effective in cases of serious power differentials, ${ }^{272}$ just to name a few. To the extent that the Ford Foundation no longer funds its research program on ADR, funding for research on these and other ADR policy questions will have to be supported not only by the Hewlett Foundation, but by universities, court and governmental units, and others interested in learning more about the effectiveness of ADR. Each of us has our pet research questions, but as the list of disputes outlined in this Article has revealed, we need empirical answers to resolve some of our conflicts and disputes.

Beyond the empirical issues revealed through evaluative research, we need more than applied research in the field. ADR has benefitted greatly from theoretical work on conflict resolution, including the conditions for cooperation studied by Robert Axelrod; $i^{273}$ prisoner's dilemma studies and strategic information and behavioral game theory; ${ }^{274}$ cognitive and social psychological approaches to information processing; behavior and judgment

269. What is an appropriate amount of time for case processing remains unclear. Litigation baselines differ widely not only in our federal and state systems, but throughout the common law world. See Roger Hanson et al., PATHS to CIVIL Justice Reform (National Center for State Courts, forthcoming.)

270. It should be possible to monitor this in some courts in which parties opt for their own providers after being urged by court procedures to use some form of ADR. There are fertile fields for testing whether parties prefer "cheaper" ADR from courts that provide such services from volunteer panels, or whether parties prefer to choose their decisionmakers at the extra cost of paying for private providers.

271. See Craig McEwen, Mediation in Context: New Questions for Research, 3 DISP. RESOL. MAG. 16 (1996). For illustrations of valuable research on mediation and other forms of ADR, beyond evaluation research, see MEDIATION RESEARCH (Kenneth Kressel et al. eds., 1989); CONFICT, COOPERATION AND JUSTICE: ESSAYS INSPIRED BY THE WORK OF MORTON DEUTSCH (Barbara Benedict Bunker et al. eds., 1995).

272. See, e.g., HERMAN ET AL., supra note 193.

273. See ROBERT AXELROD, THE EVOLUTION OF COOPERATION (1984).

274. See, e.g., DOUglas BAIRD \& ROBERT GERTNER, GAME THEORY AND THE LAW (1994); ANATOL RAPOPORT \& Albert M. CHAMMAH, Prisoner's DllemMA (1965); ERIC RASMUSEN, GAMES AND INFORMATION: AN INTRODUCTION TO GAME THEORY (2d ed. 1994). 
under uncertainty; ${ }^{275}$ and conditions under which people seek to help each other ${ }^{276}$ or seek fairness or justice ${ }^{277}$ or act from mixed motives. ${ }^{278}$ Legal dispute resolution has much to learn from other disciplines that study individual behavior and motivations (psychology), group and social interactions (sociology), economics and decision sciences, as well as cultural variations (anthropology). Thus, our narrow focus on ADR in the United States could learn from fields that have studied the contexts and cultures in which disputing is located. Finally, given ADR's growth in international trade and other matters, it is clear we will have to learn more about whether there are cross-cultural differences in disputing. ${ }^{279}$

\section{Resolving the Disputes AmONg Dispute Professionals: OF POLICY CHOICES AND PROCESS}

This Article has raised many more questions than it has answered, but I hope it has not dampened anyone's enthusiasm for ADR. "Appropriate" dispute resolution offers the possibility that parties can participate in the resolution of their problems and disputes and that they can find solutions that are helpful, efficient, and tailored to their needs. The expansion of a wide variety of practices that fall under the name of "ADR" and the current institutionalization of ADR in courts and contract clauses has both rigidified its development and provided opportunities for testing the outer limits and justice of these diverse practices.

The "jurisprudence of ADR" presents us with some difficult choices. How are we to judge the legitimacy, as well as the effectiveness of "privatized" and "aggregated" justice when our constitutional and adversarial systems have promised individual and public justice for many important

275. See, e.g., BARRIERS TO CONFLICT RESOLUTION, supta note 137; JUDGEMENT UNDER UNCERTAINTY: HEURISTICS AND BIASES (Daniel Kahneman ed., 1982); RICHARD NISBETT \& LEE ROSS, HUMAN INFERENCE: STRATEGIES AND SHORTCOMINGS OF SOCIAL JUDGMENT (1980).

276. See, e.g., ALFIE KOHN, THE BRIGHTER SIDE OF HUMAN NATURE: ALTRUISM AND EMPATHY IN EVERYDAY LIFE (1990); Carrie Menkel-Meadow, Is Altruism Possible in Lawyering?, 8 GA. ST. U. L. REV. 385 (1992).

277. See, e.g., Max H. Bazerman \& Margaret A. Neale, The Role of Faimess Considerations and Relationships in a Judgmental Perspective of Negotiation, in BARRIERS TO CONFICT RESOLUTION, supra note 137, at 86; Max H. Bazerman, Norms of Distributive Justice in Interest Arbitration, 38 INDUS. \& LAB. REL. REV. 558 (1985).

278. See WILSON, BEYOND SELF-INTEREST, supra note 136.

279. See, e.g., John L. Graham, The Japanese Negotiation Style: Characteristics of a Distinct Approach, 9 NEGOTIATION J. 123 (1993); Jeffrey Z. Rubin \& Frank E.A. Sander, Culture, Negotiation, and the Eye of the Beholder, 7 NEGOTIATION J. 249 (1991). 
issues? How can we realize some of the more humanistic goals that motivated many, like myself, to join this field? Can ADR offer the promise that new claims will be recognized when courts and legal rules will not acknowledge harms and pains? ${ }^{280}$ Can ADR be used more effectively than rigid adversarial processes for healing wounds among and between groups as well as individuals? ${ }^{281}$ What institutions should be involved in providing for and developing ADR? What is the role of the state in ADR? ${ }^{282}$ How should we evaluate the processes within ADR and the outcomes and outputs that ADR delivers? As compared to what else?

These are all difficult questions and I cannot answer them all here, but I will suggest that we have learned much from over twenty years of experience with ADR and we can develop processes for resolving these issues and tensions. If ADR has meant anything as a movement or ideology, it demonstrates that we learn from open, not rigid, stylized, or limited, less"legalistic" dialogues and conversations. So, I suggest that we broaden our questions, open the debates, and embrace more participants. Experience in ADR has changed some of my views and so I suggest that immersion in these processes is necessary to understand them. While we need evaluation and possible regulation from external sources, I believe the greatest insights will come from inside the profession, from those of us who are "true believers" but who are also capable of critical thinking. ${ }^{283}$ Let me end with a few examples.

First, my own views on two important issues have changed over the years. Although I have been concerned with the co-optation and inflexibility of court use of ADR, I now think that court ADR and even "presumptively mandatory" referrals to ADR are worth preserving. Many of the important issues about the quality of ADR providers, ethics, evaluation, purposes, and objectives of ADR have developed from the thoughtful attention of court officials, legislatures, and other regulatory bodies that are more accountable in the public sector than the market discipline private-sector usage of $A D R$. We will undoubtedly learn something from the patterns of private $A D R$ use, but to the extent that private ADR

280. See, e.g., ROBIN WEST, CARING FOR JUSTICE 94-178 (1997).

281. See, e.g., Howard Gadlin, Conflict Resolution, Cultural Differences, and the Culture of Racism, 10 NeGOTIATION J. 33 (1994).

282. When the Civil Justice Reform Act sunsets at the end of this year, courts will have to decide whether to absorb the costs of ADR within their regular budgets. Will ADR be assimilated into the mainstream functions of courts, or, like clinical legal education after 20 years of Ford Foundation funding ceased, will there simply be a few courts (like a few schools) that will be leaders in this different way of doing business?

283. Trina Grillo was a model of such a person. See Menkel-Meadow, supra note ?. 
remains so resistant to formal study and scrutiny, except when "taken to court," ${ }^{284}$ I think we will continue to learn from the more open discussions fostered by public use and debate.

Related to this interest is what I have seen to be the educative effect of "presumptively mandatory" referrals. Lawyers, especially litigators, know best how to litigate and how to fight in that controlled environment. $\mathrm{ADR}$, at least in some forms, has required lawyers and some parties to solve problems in different ways-to consider future interests, on-going relations, long-term effects, implications for third parties, and even the public relations of the choices they make in litigation. To the extent that private and public forms of ADR accomplish different things and do so in different ways, it is important that such a creative dialogue should continue. The private mini-trial produced the public summary jury trial, and each of them together has spawned other hybrid forms of dispute resolution. To the extent that the rules are clear, it seems to me that procedural creativity and process flexibility is to be encouraged. When we see abuses, we can argue for regulation and restrictions. ${ }^{285}$ The high costs of some mini-trials has in fact lessened its use in recent years.

Second, new forms of ADR in policy and community settings have opened up the ways in which we can structure decision making and offer the possibility of recommitted democratic processes. The very term "stakeholders" tells us that we can participate when we have a stake or an interest in an important conflict, issue, or dispute. To the extent that much of the public is alienated from traditional political processes, some forms of ADR permit participation in important issues before they ripen and harden into bitterly adversarial disputes.

Third, to the extent that modern disputes are rarely two sided or subject to simple binary solutions, ADR still offers greater possibilities for taking account of many issues, many parties, and more creative solutions. If "two heads are better than one," then processes that involve more than two adversaries are more likely to produce new or different ideas. To the

284. Such as in the continuing litigation about mandatory pre-dispute arbitration clauses in contracts.

285. I am among the supporters of ADR who think that many forms of pre-dispute mandatory arbitration clauses requiring waiver of statutory rights and remedies should be disallowed. We see self-policing and responsiveness to complaints in the due process protocols adopted by various ADR organizations and the continued scrutiny of courts. See, e.g., Engalla v. Permanente Med. Group, 64 Cal. Rptr. 2d 843 (1997), rev'g 43 Cal. Rptr. 2d 621 (1995). 
extent that rules, laws, and principles are designed to regulate for the general good, we can consider them, but we can also account for situations in which the general good does not do justice in a particular situation; in other contexts I have argued that "legal justice" is not always the same as "justice." 286

Fourth, ADR does not seek to supplant adjudication, but only supplement it. We may not always agree when one should be used rather than the other, but I view the current swings back and forth from private dispute resolution to demands for public justice to be continuous over time. The conversation about how much of each is appropriate serves to monitor and correct when too many cases escape the system, as well as when too many cases make access to justice impossible.

In short, I do not think that "adjudication will end." Adjudication, like all social processes, has changed and will continue to change, no doubt influenced by the exit of those who seek private justice that provides better solutions in a world that is increasingly complex and requires more modern solutions. If Justice Abella correctly noted that the justice system has realized the least amount of change of all of our major institutions since the nineteenth century, I think we are now in the process of creating a new era in justice institutions. If our current system of "trial by jury" evolved from the medieval form of "trial by combat," we may be on the verge of a new development in human disputing. The current use of "combat" as adversarial conflict might possibly give way to a world in which we do not always have to see things in terms of adversarial fights or "winner take all." Although 1 believe some tensions will always persist in this discussion about the right ratio of private to public disputes (for precedent production and system legitimacy), as well as a need for some transparency with respect to outcomes so we can see what is happening in our society, I think that current efforts to modify adjudication are creative and human efforts to fashion a more responsive justice system. So long as we keep watch, continue our research, engage in important self-regulation, and continue these discussions, I think we should not fear the end of adjudication as we know it. The dispute professionals among us, including the lawyers, will try to "handle" the conflicts and disputes among us, productively.

286. See Menkel-Meadow, supra note 5. On the outside walls of the Edward Bennett Williams Law Library in which I sit are the words, "Law is merely the means, justice is the end." 